VICTOR EMANUEL VILELA BARBUY

\title{
DA CONCEPÇÃO INDIVIDUALISTA À FUNÇÃO SOCIAL DA PROPRIEDADE: A CONTRIBUIÇÃO DA DOUTRINA SOCIAL DA IGREJA NO CENÁRIO JURÍDICO BRASILEIRO
}

Tese de Doutorado elaborada sob orientação do PROF.TITULAR IGNACIO MARIA POVEDA VELASCO, do Departamento de Direito Civil, Área de Concentração de História do Direito, da Faculdade de Direito da Universidade de São Paulo

\author{
SÃO PAULO
}




\section{RESUMO}

Título: Da concepção individualista à função social da propriedade: a contribuição da Doutrina Social da Igreja no cenário jurídico brasileiro. Tese de Doutorado submetida ao Departamento de Direito Civil da Faculdade de Direito da Universidade de São Paulo (2020).

Autor: Victor Emanuel Vilela Barbuy.

Orientador: Professor Titular Ignacio Maria Poveda Velasco.

Palavras-chave: Propriedade, Função Social, Doutrina Social da Igreja, Cenário Jurídico Brasileiro.

No presente trabalho, analisaremos a propriedade e sua função social à luz dos ensinamentos da Doutrina Social da Igreja, assim como a propriedade imobiliária no Brasil, desde a Constituição Imperial de 1824 até o Código Civil de 2002. Pretendemos demonstrar que houve, desde o início do século XIX até o momento atual, uma profunda mudança na concepção dominante da propriedade, que se livrou dos princípios do individualismo e passou a se subordinar ao primado do Bem Comum, e que tal mudança se deu, antes de tudo, pelo influxo da Doutrina Social Católica. 


\begin{abstract}
Title: From the individualistic conception to the social function of property: The contribution of the Social Doctrine of the Church in the brazilian juridical scenery. Doctorate thesis submitted to the Department of Civil Law of the Law Faculty of the University of São Paulo (2020).
\end{abstract}

Author: Victor Emanuel Vilela Barbuy

Coordinator: Titular Professor Ignacio Maria Poveda Velasco

Keywords: Property, Social Function, Social Doctrine of the Church, Brazilian Juridical Scenery.

In this work we will analyse property and its social function in light of the teachings of the Social Doctrine of the Church, as well as real estate property in Brazil, from the Imperial Constitution of 1824 to the Civil Code of 2002. We intend to demonstrate that it has been, from the beginning of the XIXth century to the present moment, a deep change in the conception of property, which has become free of the principles of individualism and subordinate to the primacy of Common Good, and that this change has been due first of all to the influence of the Catholic Social Doctrine. 


\section{RIASSUNTO}

Titolo: Dalla concezione individualista alla funzione sociale della proprietà: La contribuzione della Dottrina Sociale della Chiesa nel scenario giuridico brasiliano. Tesi di Dottorato di Ricerca presentata al Dipartimento di Diritto Civile della Facoltà di Giurisprudenza dell’Università di São Paulo - Brasile (2020).

Autore: Victor Emanuel Vilela Barbuy.

Coordinatore: Professore Titolare Ignacio Maria Poveda Velasco.

Parole chiave: Proprietà, Funzione Sociale, Dottrina Sociale della Chiesa, Scenario Giuridico Brasiliano.

Nel presente lavoro analizzeremo la proprietà e la loro funzione sociale alla luce degli insegnamenti dalla Dottrina Sociale della Chiesa, così come la proprietà immobiliare in Brasile, dalla Costituzione Imperiale del 1824 al Codice Civile del 2002. Proponemo di dimostrare che c'è stato, dall'inizio del XIX secolo al momento attuale, un cambiamento profondo nella concezione dominante della proprietà che è stata libera dai principi dell'individualismo e si diventò subortinata al primato del Bene Commune, e che tal cambiamento c'è stato dovuto, prima di tutto, all'influenza della Dottrina Sociale Cattolica. 


\section{SUMÁRIO}

RESUMO

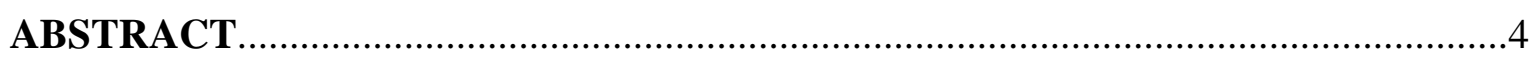

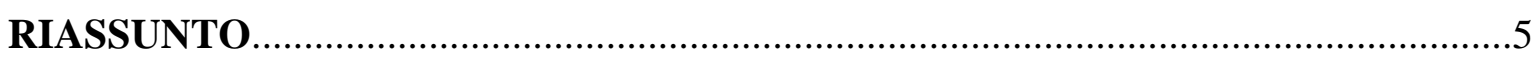

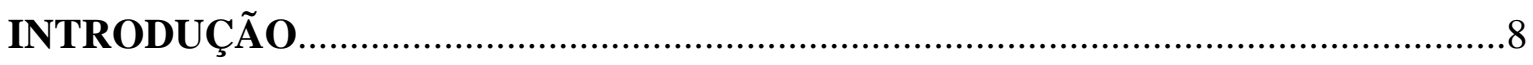

CAPÍTULO I: ASPECTOS DA DOUTRINA SOCIAL DA

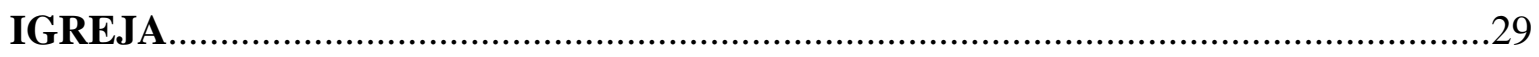

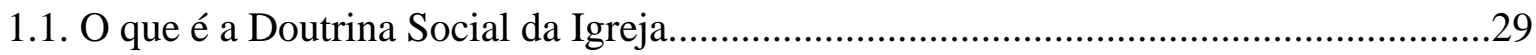

1.2. As fontes da Doutrina Social da Igreja............................................................... 30

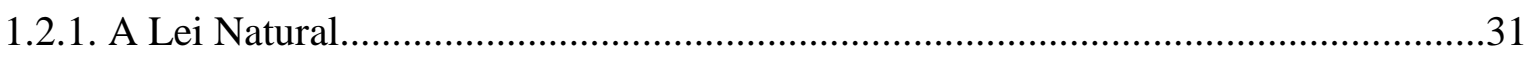

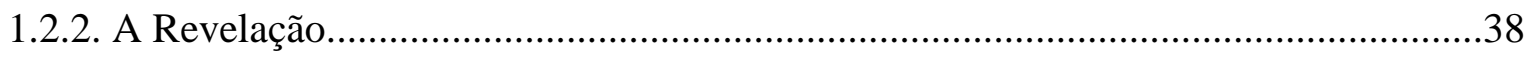

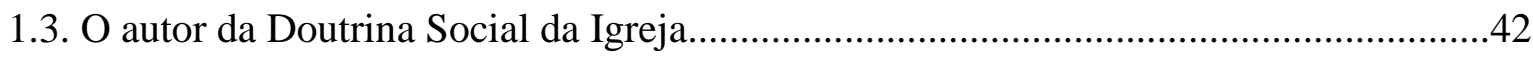

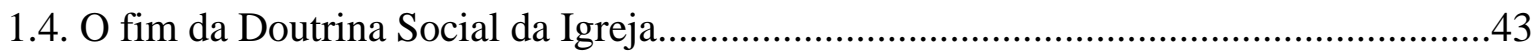

2. Algumas considerações relevantes a respeito da Doutrina Social da

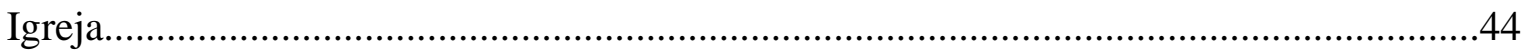

3. O homem à luz da Doutrina Social da Igreja.........................................................51

4. Os direitos fundamentais do homem conforme a Doutrina Social da

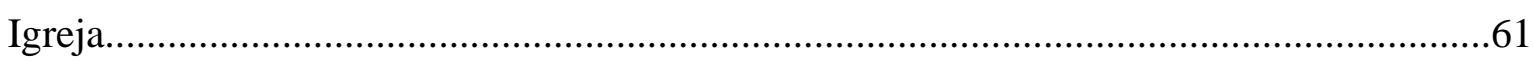

5. O Bem Comum segundo o ensinamento social católico.............................................. 70

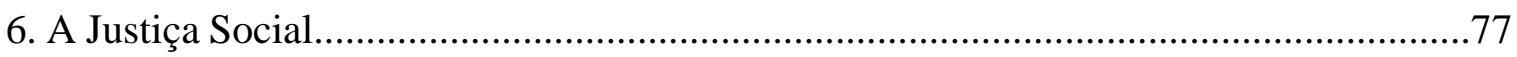

7. A propriedade e sua função social à luz da Doutrina Social da Igreja. .83

8. Sociedade e Estado segundo a Doutrina Social da Igreja............................................89

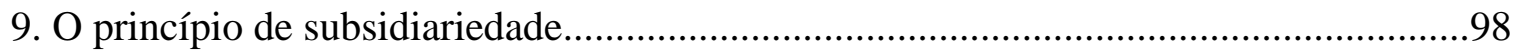

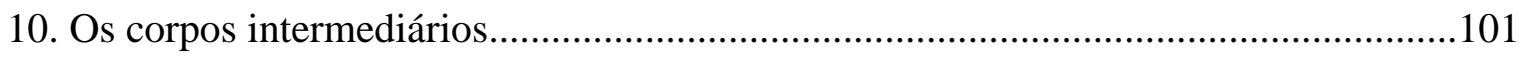

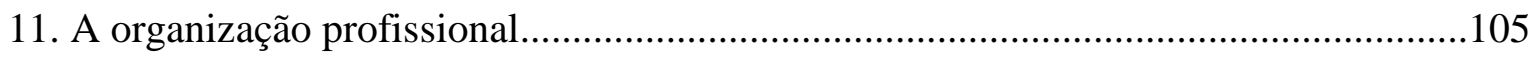

12. Capital e Trabalho conforme o ensino social católico.

13. Alguns princípios fundamentais da Doutrina Social da

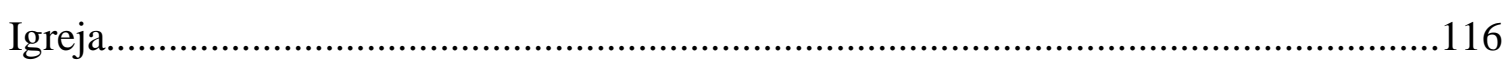


CAPÍTULO II: A PROPRIEDAdE E SUA FUNÇÃo SOCIAL À LUZ DA DOUTRINA SOCIAL DA IGREJA.

1. A propriedade no pensamento de Santo Tomás de

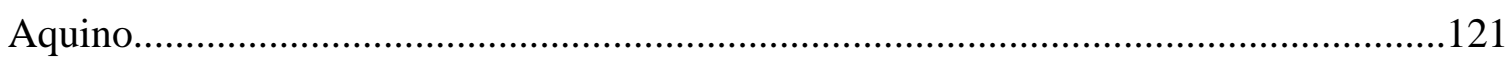

2. A propriedade na Doutrina Social da Igreja........................... 143

CAPÍTULO III: DA CONCEPÇÃO INDIVIDUALISTA À FUNÇÃO SOCIAL DA PROPRIEDADE OU DA CONSTITUIÇÃO IMPERIAL DE

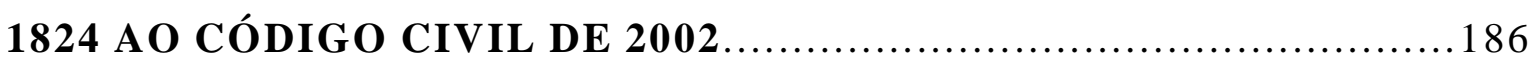

1. Considerações preliminares........................................... 186

2. Da Lei das Sesmarias à Constituição Imperial de $1824 \ldots \ldots \ldots \ldots \ldots \ldots \ldots \ldots . \ldots 196$

3. Da Constituição Imperial de 1824 ao Código Civil de $2002 \ldots \ldots \ldots \ldots \ldots . . .205$

CONCLUS ÃO

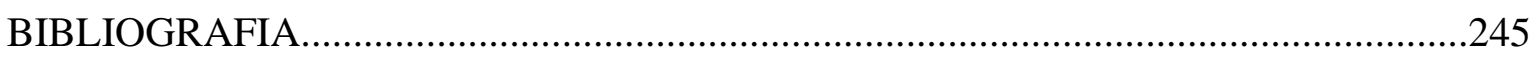




\section{INTRODUÇÃO.}

Trataremos, no presente trabalho, da propriedade imobiliária no Brasil, a partir da Constituição Imperial de 1824 até o Código Civil de 2002, passando pela Consolidação das Leis Civis, de Augusto Teixeira de Freitas (1858) e pelo Código Civil de 1916, buscando demonstrar que houve, desde o século XIX até o momento atual, uma profunda mudança na concepção dominante de propriedade e que tal mudança se deu, antes e acima de tudo, por influência da Doutrina Social da Igreja. Com efeito, se na décima nona centúria predominava uma concepção de propriedade de caráter essencialmente individualista, que via o direito de propriedade como um direito absoluto, intocável e sobreposto ao bem da comunidade, hoje prevalece a visão, em nosso entender mais justa, de que a propriedade, conquanto seja um direito pessoal, possui uma função social e de que o proprietário, no exercício de seus legítimos direitos e no uso de seus bens, deve levar em conta o bem da coletividade, de que o Estado é representante e guardião.

Havendo feito referência ao caráter essencialmente individualista da concepção de propriedade preponderante no século XIX, julgamos ser mister assinalar que este não se confunde com o caráter individual da propriedade, caráter este que lhe é intrínseco, tanto quanto a sua dimensão social. Em verdade, como ressaltou Miguel Reale, a propriedade, do mesmo modo que o deus romano Janus, possui duas faces, uma delas voltada para o indivíduo e a outra para a sociedade. ${ }^{1}$

Renovada e sistematizada a partir da Encíclica Rerum Novarum (1891), do Papa Leão XIII, a Doutrina Social da Igreja ou, em outras palavras, o pensamento social cristão é, contudo, muito anterior a tal documento pontifício, sendo mesmo tão antigo quanto a própria Igreja e tendo se desenvolvido conforme as exigências de cada época. Neste

\footnotetext{
${ }^{1}$ O Projeto do novo Código Civil, São Paulo, Saraiva, 1999, p. 155.
} 
sentido, assim escreveu o Papa São João Paulo II, na Encíclica Laborem Exercens, dada em Castel Gandolfo em 1981, no nonagésimo aniversário da Rerum Novarum:

o dedicar atenção ao problema [social] remonta a tempos muito para além dos últimos noventa anos. A doutrina social da Igreja, efetivamente, tem a sua fonte na Sagrada Escritura, a começar do Livro do Gênesis e, em particular no Evangelho e nos escritos dos tempos apostólicos. Dedicar atenção aos problemas sociais faz parte desde os inícios do ensino da Igreja e da sua concepção do homem e da vida social e, especialmente, da moral social que foi sendo elaborada segundo as necessidades das diversas épocas. Um tal patrimônio tradicional foi depois herdado e desenvolvido pelo ensino dos Sumos Pontífices sobre a moderna “questão social”, a partir da Encíclica Rerum Novarum..$^{2}$

Dentre os mais relevantes princípios da Doutrina Social da Igreja podemos destacar a dignidade da pessoa humana, criada por Deus à sua imagem e semelhança e dotada de direitos e deveres fundados na Lei Natural; o primado do Bem Comum sobre os interesses particulares; a autoridade a serviço do ente humano e do Bem Comum; a justa autonomia da família e dos demais grupos sociais naturais ou corpos intermediários; o princípio de subsidiariedade e a ação supletiva do Estado na economia; o trabalho em relação de harmonia com o capital e compreendido como uma ação humana que deve ser remunerada com um justo salário e não como uma mercadoria, e, por fim mas não menos importante, o direito de propriedade privada com as limitações impostas pela Justiça e pelo Bem Comum ou, em outros termos, subordinada à sua função social. ${ }^{3}$

\footnotetext{
${ }^{2}$ Carta Encíclica Laborem Exercens, dada em Castel Gandolfo a 14 de setembro de 1981. Disponível em: http://w2.vatican.va/content/john-paul-ii/pt/encyclicals/documents/hf_jp-ii_enc_14091981_laboremexercens.html. Acesso em 10 de agosto de 2019.

${ }^{3}$ Sobre a Doutrina Social da Igreja e seus princípios: Fernando Bastos de ÁVILA, Pequena enciclopédia de Doutrina Social da Igreja, São Paulo, Edições Loyola, 1991; Jean-Yves CALVEZ e Jacques PERRIN, Igreja e Sociedade Económica: O ensino social dos papas de Leão XIII e Pio XII (1878-1958), Tradução de Agostinho Veloso, S.J., Porto, Livraria Tavares Martins, 1960; Ferdinand CAVALLERA, Précis de la Doctrine Sociale Catholique, nouvelle édition mise à jour, Paris, Action Populaire; Éditions SPES, 1937; Constant van GESTEL, A Igreja e a Questão Social, Tradução e adaptação do Padre Fernando Bastos de Ávila, Rio de Janeiro, Livraria Agir Editora, 1956; Monsenhor GUERRY, A Doutrina Social da Igreja, Lisboa, Livraria Sampedro, 1960; José Miguel IBÁÑEZ LANGLOIS, Doutrina Social da Igreja, Tradução de Maria da Graça de Mariz Rozeira, $2^{a}$ edição, Lisboa, Rei dos Livros, 1994; Luiz Carlos LESSA, Dicionário de Doutrina Social da Igreja: Doutrina Social da Igreja de A a Z, São Paulo, LTr, 2004; Alberto MARTÍN ARTAJO e Maximo CUERVO, Doctrina Social Católica de León XIII y Pío XI, Barcelona, Labor, 1939; Johannes MESSNER, Ética Social (o Direito Natural no Mundo Moderno), Tradução de Alípio Maia de Castro, São Paulo, Editora Quadrante, Editora da Universidade de São Paulo, s/d; Andrea ODDONE, SJ, Princípios cristãos para o estudo da
} 
Muitos são os autores que salientaram a profunda influência exercida, no Brasil, pela Doutrina Social da Igreja no campo do Direito do Trabalho. Oliveira Vianna, por exemplo, ressaltou o fato de haver sido a Doutrina Social da Igreja a principal fonte de inspiração do nosso Direito Laboral $^{4}$, cumprindo frisar que, como consultor jurídico do Ministério do Trabalho, contribuiu o autor de Direito do Trabalho e Democracia Social enormemente na obra de edificação do Direito do Trabalho e da Justiça do Trabalho no País, tendo sido a legislação laboral pátria “inspirada e em grande parte elaborada" por ele, como bem acentuou Paulo Edmur de Souza Queiroz. ${ }^{5}$ No mesmo sentido, Arnaldo Süssekind, um dos cinco membros da comissão que elaborou a Consolidação das Leis do Trabalho (CLT), observou que a aludida comissão se baseou sobretudo na Encíclica Rerum Novarum, nas conclusões do I Congresso Brasileiro de Direito Social (em larga medida inspiradas na Doutrina Social da Igreja) e nas convenções da Organização Internacional do Trabalho (OIT) para realizar seu labor de consolidar a legislação trabalhista brasileira, complementada e corrigida naquilo que a comissão julgou necessário. ${ }^{6}$

Menos numerosos têm sido, porém, aqueles que sublinham a importância fundamental da Doutrina Social da Igreja na elaboração do conceito de função social da propriedade e na mudança da concepção de

Sociologia, Tradução do Padre Carlos Piasentin, CPS, Prefácio de Plínio Salgado, São Paulo, Gráfica Tibiriçá, 1952; Moacyr Velloso Cardoso de OLIVEIRA, A Doutrina Social ao alcance de todos, São Paulo, LTr, 1991; PONTIFÍCIO CONSELHO “JUSTIÇA E PAZ”, Compêndio da Doutrina Social da Igreja, Tradução da Conferência Nacional dos Bispos do Brasil (CNBB), $7^{\text {a }}$ edição, São Paulo, Paulinas, 2011; Carlos RAMALHETE, Doutrina Social da Igreja: uma introdução, São Paulo, Quadrante, 2017; G. C. RUTTEN, OP, A Doutrina Social da Igreja, segundo as encíclicas "Rerum Novarum" e "Quadragesimo Anno, Rio de Janeiro, Livraria AGIR Editora, 1946; Carlos Alberto SACHERI, A Ordem Natural: Um compêndio sobre a Doutrina Social da Igreja, Tradução de Roberto Romano, Belo Horizonte, Edições Cristo Rei, 2014; Plínio SALGADO, Direitos e deveres do Homem, $4^{\mathrm{a}}$ edição, in Obras completas, $2^{\mathrm{a}}$ edição, volume 5, São Paulo, Editora das Américas, 1957; José Pedro Galvão de SOUSA; Clovis Lema GARCIA; José Fraga Teixeira de CARVAlHO, Dicionário de Política, São Paulo, T.A. Queiroz, 1998, pp. 189-191; UNIÃO INTERNACIONAL DE ESTUDOS SOCIAIS, Código Social: esboço de uma síntese social católica, São Paulo, Centro D. Vital, 1932; VV.AA., A encíclica Mater et Magistra e a hodierna questão social, Tradução de Carlos Ferrario, São Paulo, Edições Paulinas, 1962; Pedro Soares MARTínEZ, Economia Política, $8^{\mathrm{a}}$ edição revista, Coimbra, Livraria Almedina, 1998, pp. 289-307.

${ }^{4}$ Direito do Trabalho e Democracia Social (o problema da incorporação do trabalhador no Estado), Rio de Janeiro, Livraria José Olympio Editora, 1951.

${ }^{5}$ Sociologia política de Oliveira Vianna. São Paulo, Editora Convívio, 1975, p. 97.

${ }^{6}$ O cinqüentenário da CLT, in Revista da Academia Brasileira de Letras Jurídicas, vol. 7, $\mathrm{n}^{\circ}$ 4, Rio de Janeiro, jul.-dez./1993, p. 16. As conclusões do I Congresso Brasileiro de Direito Social, promovido pelo Instituto de Direito Social, iniciado em São Paulo e encerrado no Rio de Janeiro em 1941 (Cf. Antônio Ferreira CESARINO JUNIOR, Direito Social, São Paulo, LTr; Editora da Universidade de São Paulo, 1980, p. 34) foram publicadas na Revista de Direito Social (n. 2, São Paulo, set./1941), editada pelo mencionado Instituto. 
propriedade privada no Brasil, ainda que não seja pequeno o número daqueles que ressaltaram tal relevância. Com efeito, essa fulcral importância dos ensinamentos sociais da Igreja naquilo que podemos chamar de evolução do conceito de propriedade em nosso País tem sido assinalada por diversos juristas pátrios, a exemplo de Fernando Sodero ${ }^{7}$ e Telga de Araújo. ${ }^{8}$

Isto posto, voltemos a tratar da propriedade. Conjunto de poderes que o proprietário tem sobre a coisa, a propriedade é não somente o mais amplo dentre os denominados direitos reais, como também o mais amplo dentre os direitos subjetivos, constituindo-se, em última análise, na pedra angular ou espinha dorsal, de todo o Direito Privado. Direito real por excelência e direito subjetivo padrão, a propriedade é um direito natural e fundamental da pessoa humana, que deve ser reconhecido e protegido pelo Estado.

Cumpre salientar que, consoante já aduzia o Conselheiro Lafayette em fins da década de 1870 , todas as tentativas no sentido de tirar da propriedade o seu caráter de direito pessoal, individual, e subordiná-la ao império despótico do Estado ou da simples comunidade têm se esboroado diante da rocha da experiência, ${ }^{9}$ posto que, como ressaltou Giambattista Vico, "as coisas fora de seu estado natural não se tornam adequadas nem duram". 10

Assim, a propriedade não pode ser abolida pelo Estado, que, entretanto, como guardião do Bem Comum, detém o direito de impor restrições e obrigações ao exercício de tal direito, tanto a fim de prevenir e punir abusos quanto para melhor satisfazer os legítimos interesses da comunidade. ${ }^{11}$

\footnotetext{
${ }^{7}$ Direito agrário e reforma agrária, São Paulo, Livraria Legislação Brasileira, 1968.

${ }^{8}$ Função social da propriedade, in Rubens Limongi FRANÇA (coordenador), Enciclopédia Saraiva do Direito, vol. 39. São Paulo, Saraiva, s/d, p. 7.

${ }^{9}$ Direito das coisas, Adaptação ao Código Civil por José Bonifácio de Andrada e Silva, 5ª edição, volume I, Rio de Janeiro, Livraria Editora Freitas Bastos, 1943, p. XI.

${ }^{10}$ Scienza Nuova, 134, in Autobiografia, Poesie, Scienza Nuova, $3^{a}$ edição, Milano, Garzanti, 2006, p. 246. Tradução nossa.

${ }^{11}$ Cf. Constant van GESTEL, A Igreja e a Questão Social, Tradução e adaptação do Padre Fernando Bastos de Ávila, Rio de Janeiro, Livraria Agir Editora, 1956, p. 217.
} 
Por Bem Comum entendemos, com base nas definições de Viktor Cathrein ${ }^{12}$ e de São João XXIII, ${ }^{13}$ o conjunto de condições aptas a permitir o integral desenvolvimento do homem, da família e dos demais grupos naturais integrantes da sociedade. ${ }^{14}$ Bem de todos e de cada um, é ele o bem da sociedade, das pessoas consideradas não isoladamente, mas sim em comum; o bem que toca a todos, em bloco, e também a cada um, em particular, e é, ademais, o bem intermediário entre o bem particular e o Bem Divino ou Bem Supremo, que é Deus. ${ }^{15}$

"Maior e mais divino que o bem privado", na expressão de Santo Tomás de Aquino, ${ }^{16}$ o Bem Comum, embora diverso deste, ${ }^{17}$ tem para com ele uma relação de afinidade e de harmonia. ${ }^{18}$ Há entre ambos, em verdade, contínua interação, isto é, comunhão e dualidade ininterrupta, ${ }^{19}$ de forma que, como prelecionou o Aquinate, aquele que busca o Bem Comum busca também o seu próprio bem, uma vez que não pode existir o bem próprio sem o Bem Comum, seja este da família, da cidade ou da pátria, da mesma forma que, sendo a pessoa parte de uma casa e de uma cidade, deve buscar aquilo que é bom para ela pelo prudente cuidado do Bem Comum. ${ }^{20}$

${ }^{12}$ Filosofia Morale, volume II, Tradução italiana, Firenze, Libreria Editrice Fiorentina, 1913, p. 563.

13 Carta Encíclica Mater et Magistra, dada em Roma em 15 de maio de 1961. Disponível em: http://w2.vatican.va/content/john-xxiii/pt/encyclicals/documents/hf_j-xxiii_enc_15051961_mater.html.

Acesso em 10 de agosto de 2019.

${ }^{14}$ Cf. Victor Emanuel Vilela BARBUY, Justiça e Bem Comum, in Marcelo Roland ZOVICO (Organizador), Filosofia do Direito: Estudos em homenagem a Willis Santiago Guerra Filho, São Paulo, Editora Clássica, 2012, p. 323. Sobre o conceito de Bem Comum: Alfredo BUZAID, Humanismo político (conferência proferida em 6 de julho de 1973, na Escola Superior de Guerra), Rio de Janeiro, Ministério da Justiça, 1973, pp. 28-31; Luiz Carlos LESSA, Dicionário de Doutrina Social da Igreja: Doutrina Social da Igreja de A a Z, São Paulo, LTr, 2004, pp. 48-52; Suzanne MICHEL, La notion thomiste du Bien Commun, Prefácio de Georges Renard, Paris, Librairie Philosophique J. Vrin, 1932; Gilberto Callado de OLIVEIRA, Filosofia da política jurídica, $2^{\text {a }}$ edição, Florianópolis, Conceito Editorial, 2008, pp.189-198; José Pedro Galvão de SOUSA; Clovis Lema GARCIA; José Fraga Teixeira de CARVALHO, Dicionário de Política, São Paulo, T.A. Queiroz, 1998, pp. 60-62.

${ }^{15}$ Cf. Suzanne MICHEL, La notion thomiste du Bien Commun, cit., p. 18.

${ }^{16}$ Do governo dos príncipes ao Rei de Cipro, in Arlindo Veiga dos SANTOS, (Organizador e tradutor), Filosofia política de Santo Tomás de Aquino, $3^{a}$ edição melhorada, Prefácio de Leonardo Van Acker, São Paulo, José Bushatsky, Editor, 1956, p. 98.

${ }^{17}$ Cf. Santo Tomás de AQUINO, Suma Teológica, II $^{\mathrm{a}}$ parte da II ${ }^{\mathrm{a}}$ parte, questão 58 , artigo $7^{\circ}$, resposta à segunda objeção, Tradução de Alexandre Corrêa, $1^{a}$ edição, volume XIV, São Paulo, Livraria Editora Odeon, 1937, p. 35; Alfredo BUZAID, Humanismo político, cit., p. 30; Suzanne MICHEL, La notion thomiste du Bien Commun, p. 43; Gilberto Callado de OLIVEIRA, Filosofia da política jurídica, cit., p. 193; José Pedro Galvão de SOUSA; Clovis Lema GARCIA; José Fraga Teixeira de CARVALHO, Dicionário de Política, cit., p. 60.

${ }^{18}$ Cf. Suzanne MICHEL, La notion thomiste du Bien Commun, p. 53.

${ }^{19}$ Alfredo BUZAID, Humanismo político, cit., loc. cit.

${ }^{20}$ Suma Teológica, Segunda parte da segunda parte, questão 47, artigo 11, solução, Tradução de Alexandre Corrêa, Organização de Rovílio Costa e Luís Alberto De Boni, Introdução de Martin Grabmann, $2^{\mathrm{a}}$ edição, 
Cônscio de seu direito de impor restrições e limitações ao proprietário, bem como do caráter a um só tempo individual e social da propriedade, sublinhado, dentre outros, por Leão XIII, na Encíclica Rerum Novarum, ${ }^{21}$ e por Pio XI, na Encíclica Quadragesimo Anno, ${ }^{22}$ o Estado deve se ocupar do regime de propriedade com o intuito de adaptá-lo à sua função social ou, em outras palavras, deve regrá-lo a fim de fazer com que a propriedade seja efetivamente instrumento do Bem Comum. ${ }^{23}$

Dito isto, cumpre sublinhar que, conforme enfatizou Francesco Vito, o caráter a um só tempo individual e social da propriedade não destrói ou enfraquece, antes fortalece o direito de propriedade. ${ }^{24}$

Se o século XIX foi o apogeu do período a que Lúcio Craveiro da Silva denominou "era individualista liberal", ${ }^{25}$ a partir do término da Primeira Grande Guerra, entrou o Ocidente no período que o mesmo Craveiro da Silva chamou de "a Idade do Social". ${ }^{26}$ Desde então já não tem prevalecido, no espírito legislativo, o pernicioso absolutismo que imperava no conceito do direito de propriedade, conferindo ao titular de tal direito excepcionais prerrogativas, em detrimento dos mais caros interesses da coletividade. ${ }^{27}$

Destarte, após um longo período de predomínio do mais radical individualismo jurídico, que concebeu a propriedade como um direito absoluto e oposto ao Bem Social, e que, como salientou San Tiago Dantas, talvez jamais tenha tido uma expressão legislativa plena, ${ }^{28}$ tem imperado,

Porto Alegre, Escola Superior de Teologia São Lourenço de Brindes, Livraria Sulina Editora; Caxias do Sul, Universidade de Caxias do Sul, 1980, pp. 2421-2422.

21 Carta Encíclica Rerum Novarum, dada em Roma a 15 de maio de 1891. Disponível em: https://w2.vatican.va/content/leo-xiii/pt/encyclicals/documents/hf_1-xiii_enc_15051891_rerumnovarum.html. Acesso em 10 de agosto de 2019.

${ }^{22}$ Carta Encíclica Quadragesimo Anno, dada em Roma a 15 de maio de 1931. Disponível em: https://w2.vatican.va/content/pius-xi/pt/encyclicals/documents/hf_p-xi_enc_19310515_quadragesimoanno.html. Acesso em 10 de agosto de 2019.

${ }^{23}$ Cf. Constant van GESTEL, A Igreja e a Questão Social, cit., loc. cit.

${ }^{24}$, Transformações econômicas e doutrina social católica, in VV.AA., A encíclica Mater et Magistra e a hodierna questão social, Tradução de Carlos Ferrario, São Paulo, Edições Paulinas, 1962, pp. 32-33.

${ }^{25}$ A idade do social: Ensaio sobre a evolução da sociedade contemporânea, $2^{\mathrm{a}}$ edição, aumentada, Braga, Livraria Cruz, 1959, p. 25.

${ }^{26}$ Idem, loc. cit.. Grifos em itálico no original.

${ }^{27}$ Cf. Carlos Alberto Dabus MALUF, Limitações ao direito de propriedade, $3^{\mathrm{a}}$ edição revista e atualizada, Prefácio de Miguel Reale, São Paulo, Editora Revista dos Tribunais, 2011, p. 23.

${ }^{28}$ Programa de Direito Civil, III, Revisão de texto e anotações de João Gomes de Bezerra Câmara, $2^{\mathrm{a}}$ edição, Rio de Janeiro, Editora Rio, 1981, p. 116. Com efeito, mesmo o Código Civil Napoleônico de 1804 e o Código 
desde o ocaso do há pouco aludido conflito mundial, uma nova e mais justa concepção de propriedade. Segundo esta, a propriedade, conquanto seja um direito individual, possui uma função social, e o proprietário, na utilização de seus bens, deve tomar sempre em consideração o bem da coletividade, cujo representante é, como restou dito, o Estado.

Assim, liberta dos cânones individualistas por um imperativo de ordem social e econômica, a propriedade tende cada vez mais a se subordinar aos ditames do Bem Comum. ${ }^{29}$ Em outras palavras, devendo atender a um dever de boa gestão, de boa administração, em vista do bem pessoal e do Bem Comum, a propriedade passou a se apresentar revestida de um profundo caráter social, afastando-se cada vez mais da concepção individualista que inspirou, dentre outros diplomas legais, o Código Civil Brasileiro de $1916,{ }^{30}$ bem como, em maior ou menor medida, todos os projetos de Código Civil Pátrio que o precederam.

Isto posto, é mister sublinhar que mesmo o Esboço de Código Civil de Teixeira de Freitas, de 1864, em que pese o fato de seu autor, inspirado em preleções de Heinrich Ahrens, ${ }^{31}$ reconhecer a existência do elemento social da propriedade, ${ }^{32}$ não deixou de refletir, em certa medida, o individualismo jurídico predominante no tempo de sua elaboração. Tal tendência já era percebida também na Consolidação das Leis Civis, realizada na década de 1850 pelo mesmo Teixeira de Freitas.

Como observou Miguel Reale, poder-se-á dizer que no espírito de Teixeira de Freitas se casam, “embora sem explícito tratamento filosófico unitário, elementos da escola histórica e do direito natural concebido como exigência ideal da razão, em função da realidade", numa compreensão a um só tempo individual e social do Direito, tal como resulta da preleção que acolhe de Ahrens sobre a propriedade, entendida como "composição

Civil Italiano de 1865, dois máximos monumentos do individualismo jurídico, previram restrições ao direito de propriedade. Como observou Rui Geraldo Camargo Viana, mesmo tais códigos, que proclamaram que o direito de propriedade possui um caráter absoluto, apresentaram a restrição, "pouco cuidada pelos entusiastas da propriedade sem peias", do "uso proibido pelas leis ou regulamentos" (O parcelamento do solo urbano, Rio de Janeiro, Forense, 1985, p. 12.).

${ }^{29}$ Cf. Carlos Alberto Dabus MALUF, Limitações ao direito de propriedade, loc. cit.

30 Idem, pp. 23-24.

${ }^{31}$ Cours de Droit Naturel ou de Philosophie du Droit, $4^{\mathrm{a}}$ edição, Bruxelles, Meline, Cans \& Ce., 1853, p. 390.

${ }^{32}$ Consolidação das Leis Civis, terceira edição mais augmentada, Rio de Janeiro, 1876, volume 1, p. CXCII. 
de dois elementos, um voltado para o indivíduo e outro voltado para a sociedade, não devendo um ser absorvido pelo outro", tendo em vista o fato de serem ambos "reflexos das relações orgânicas que devem existir entre o indivíduo e a sociedade". ${ }^{33}$ Do mesmo modo, contudo, poder-se-á dizer que o autor do Esboço não deixou de sofrer alguma influência da concepção individualista do direito de propriedade, predominante em sua época e que teve seus dois grandes marcos legislativos no Código Civil Francês de 1804, também conhecido como Código Napoleão, e no Código Civil Italiano de 1865.

Tendo feito referência, por mais de uma vez, à concepção individualista do direito de propriedade, que caracterizou o pensamento do século XIX, julgamos ser relevante frisar que os juristas adeptos de tal concepção pouco cuidaram, em suas obras, da restrição à propriedade do "uso proibido pelas leis e regulamentos", presente no Código Civil Francês de 1804, assim como no Código Civil Italiano de 1865, e pintaram o Direito Romano como um Direito essencialmente individualista, coisa que este, em verdade, jamais foi. ${ }^{34}$ Com efeito, diferentemente do que sustentaram os estudiosos individualistas do Direito Romano do décimo nono século, sempre existiram diversas limitações ao direito de propriedade no Direito Romano, limitações estas que se encontram, no período pré-clássico, estabelecidas na Lei das XII Tábuas e se tornaram mais numerosas no denominado período clássico. ${ }^{35}$

Um ano antes do final da Primeira Grande Guerra, a Constituição Mexicana de 1917 foi a primeira constituição escrita a consagrar o

\footnotetext{
${ }^{33}$ Teixeira de Freitas e o sentido social do Direito, in Figuras da inteligência brasileira, $2^{\mathrm{a}}$ edição, São Paulo, Siciliano, 1994, pp. 37-38.

${ }^{34}$ Cf. Jean-Philippe Lévy, História da propriedade, Tradução de Fernando Trigueiro, Lisboa, Estampa, 1973 , p. 28; Carlos Alberto Dabus MALUF, Limitações ao direito de propriedade, $3^{\mathrm{a}}$ edição revista e atualizada, Prefácio de Miguel Reale, São Paulo, Editora Revista dos Tribunais, 2011, p. 33.

${ }^{35}$ Sobre tais limitações ao direito de propriedade em Roma: José Carlos Moreira ALVES, Direito Romano, $6^{\mathrm{a}}$ edição, Rio de Janeiro, Forense, 1987, volume 1, pp. 354 e ss; Luigi Capogrossi COLOGNESI, Proprietà (Diritto Romano), in Enciclopedia del Diritto, Milano, Giuffrè, 1988, volume 37, pp. 189 e ss; IMBERT, Jean, O Direito antigo e a sua projecção no Direito moderno, Tradução de Maria Rosa e Victor Matos, Coimbra, Livraria Almedina, 1966; DI MARZO, Salvatore, Proprietà (Diritto Romano), in Nuovo Digesto Italiano, Torino, UTET, 1939, volume 17, pp. 670 e ss.; Carlos Alberto Dabus MALUF, Limitações ao direito de propriedade, cit., pp. 34-35; Fulvio MAROI, Proprietà, in SCIALOJA, Vittorio (Dir.), Dizionario pratico del Diritto Privato, Milano, Vilardi, volume 5, pp. 693 e ss.; Baldassarre SQUITTI, Proprietà (Diritto Romano), in Enciclopedia giuridica italiana, Milano, Società Editrice, 1901, volume, parte 4, pp. 143 e ss.
} 
princípio da função social da propriedade, ao dispor, no artigo 27, que "a Nação terá, a todo tempo, o direito de impor à propriedade privada as determinações ditadas pelo interesse público". Dois anos mais tarde, tal princípio foi igualmente consagrado pela Constituição de Weimar, que, no artigo 153, estabeleceu que "a propriedade obriga" e que "seu uso constitui, consequentemente, um serviço para o Bem Comum [Gemeine Beste]". Como bem se pode notar, ambas as aludidas constituições adotaram a ideia de função social, mas ainda não tal expressão.

No ano seguinte, isto é, em 1920, a Carta de Carnaro (em italiano Carta del Carnaro), da efêmera Regência Italiana de Carnaro, em Fiume, redigida pelo sindicalista Alceste De Ambris e reescrita de forma mais bela e poética pelo escritor e poeta Gabriele D’Annunzio, Comandante da aludida Regência, foi a primeira constituição escrita a não apenas consagrar o princípio da função social da propriedade, mais precisamente segundo sua concepção positivista, como também a empregar tal expressão. Com efeito, o item IX de tal documento, que, aliás, não teve expressão prática, como assinalou Tasso da Silveira, ${ }^{36}$ se inicia com a afirmação de que "o Estado não reconhece a propriedade como o domínio absoluto da pessoa sobre a coisa, mas a considera como a mais útil das funções sociais", afirmando, em seguida, que "nenhuma propriedade pode ser reservada à pessoa quase como se fosse uma parte desta e tampouco pode ser lícito que tal proprietário negligente a deixe inerte ou dela disponha de modo mau, com exclusão de qualquer outro", e que o trabalho é o "único título legítimo de domínio sobre quaisquer meios de produção e de comércio".

Dito isto, vale sublinhar que a expressão "função social" foi cunhada por Auguste Comte, ${ }^{37}$ que, aliás, tratou especificamente da função social da propriedade, tal como a compreendia, no primeiro tomo de seu Système de politique positive. Assim escreveu Comte no aludido livro, dado à luz em 1851:

\footnotetext{
${ }^{36}$ Estado Corporativo, Rio de Janeiro, Livraria José Olympio Editora, 1937, p. 177.

${ }^{37}$ Cours de Philosophie Positive, tomo quarto, Paris, Bachelieur, Imprimeur-Libraire, 1839, p. 215, nota.
} 
Em todo o estado normal da humanidade, cada um e qualquer cidadão constitui realmente um funcionário público, cujas atribuições mais ou menos definidas determinam a um só tempo obrigações e pretensões. Este princípio universal deve certamente se estender até a propriedade, na qual o positivismo vê sobretudo uma indispensável função social destinada a formar e administrar os capitais por meio dos quais cada geração prepara os trabalhos da seguinte. Sabiamente concebida, esta apreciação normal enobrece a sua possessão sem restringir a sua justa liberdade e mesmo a fazendo mais respeitável. ${ }^{38}$

Inspirado no pensamento de Comte, Léon Duguit sustentou, em seu Manuel de Droit Constitutionnel, publicado em 1911, que "a propriedade não é um direito, é uma função social". ${ }^{39}$ Esta concepção da propriedade como função social difere da concepção de propriedade adotada pela Doutrina Social da Igreja, que, fundada nas preleções de Santo Tomás de Aquino, proclama que a propriedade é um direito natural condicionado aos deveres do proprietário para com o Bem Comum, tendo e não sendo uma função social. ${ }^{40}$

Foi esta última concepção de função social de propriedade, em nosso sentir, aliás, mais justa, ponderada e equilibrada, aquela adotada pelo ordenamento jurídico pátrio desde o Estatuto da Terra (1964), documento sobre o qual, a propósito, influiu poderosamente a Doutrina Social da Igreja e que foi o primeiro a consagrar, em nosso País, a expressão "função social”. Aliás, mesmo antes do Estatuto da Terra tal concepção de função social da propriedade já fora consagrada, em nosso entender, nas Constituições de 1934 e de 1946, em que, no entanto, não aparece a expressão "função social da propriedade".

\footnotetext{
${ }^{38}$ Système de politique positive ou Traité de Sociologie, instituant la Religion de l'Humanité, Tomo I, Paris, Librairie Scientifique-Industrielle de L. Mathias, p. 156. Tradução nossa.

${ }^{39}$ Manuel de droit constitutionnel. $2^{\mathrm{a}}$ ed. Paris: De Boccarel, 1911, p. 101.

${ }^{40}$ Cf. Victor Emanuel Vilela BARBUY, Justiça e Bem Comum, in Marcelo Roland ZOVICO (Organizador), Filosofia do Direito: Estudos em homenagem a Willis Santiago Guerra Filho, São Paulo, Editora Clássica, 2012, p. 326.
} 
A visão segundo a qual a propriedade é uma função social, que tem em Duguit o seu máximo expoente, corresponde à 'posição da chamada teoria interna dos direitos fundamentais, ao passo que a concepção que considera que a propriedade não é uma função social, mas tem uma função social que a limita, sustentada pela Doutrina Social da Igreja e por juristas como o austríaco Karl Renner, corresponde à posição da denominada teoria externa de tais direitos. ${ }^{41}$ A teoria interna pressupõe a existência de somente um objeto, o direito e seus limites (imanentes), enquanto a teoria externa divide tal objeto em dois, entendendo que há, em primeiro lugar, o direito em si, e, separadas dele, as suas restrições. ${ }^{42}$

Como demonstrou Otavio Luiz Rodrigues Junior, a teoria externa da propriedade é a mais adequada ao modelo constitucional pátrio, posto que não elimina o conteúdo do fundamental direito de propriedade e tampouco “o alija de elementos essenciais por métodos retóricos de pré-exclusão de seu suporte fático". O nível de concretização dos direitos fundamentais é integrado, segundo Rodrigues Junior, pela atuação do legislador civil, que bem o fez no Código Civil de 2002, abandonando assim o discurso ideológico segundo o qual haveria uma preponderância da função social da propriedade sobre o direito a esta, sem embargo de condicionar, como é justo, a propriedade ao exercício de sua função social. ${ }^{43}$

Enquanto a Doutrina Social da Igreja vê na propriedade um duplo caráter individual e social, Duguit via o caráter social da propriedade, mas não o caráter individual desta e, assim, em nosso sentir, acabava, em última análise, por negar a propriedade privada, bem como a própria individualidade da pessoa humana, que necessita de bens particulares para alcançar o seu desenvolvimento integral. Neste sentido, como fez ressaltar Luciano de Camargo Penteado, a Doutrina Social Católica tem uma posição sensata, ao afirmar a necessidade de se atender à função social da

41 Cf. Otavio Luiz RODRIGUES Junior Propriedade e função social: exame crítico de um caso de “constitucionalização” do Direito Civil, in Marcelo Rebelo de SOUSA; Fausto de QUADROS; Eduardo VeraCruz PINTO (Coordenadores), Estudos em homenagem ao Professor Doutor Jorge Miranda, Coimbra, Coimbra Editora, p. 81.

${ }^{42}$ Cf. Virgílio Afonso da SILVA, O conteúdo essencial dos direitos fundamentais e a eficácia das normas constitucionais, in Revista de Direito do Estado, Volume 4, Rio de Janeiro, 2006, pp. 38-39.

43 Cf. Otavio Luiz RODRIGUES Junior Propriedade e função social: exame crítico de um caso de “constitucionalização” do Direito Civil, cit., p. 84. 
propriedade e, ao mesmo tempo, preservar a titulação privada desta. ${ }^{44}$ Em uma palavra, a função social da propriedade, concebida à luz das preleções da Doutrina Social da Igreja, limita um direito titulado e reconhecido como tal e dizer "função social" não significa, na frase de Luciano de Camargo Penteado, "ser socialista, nem muito menos comunista". 45

No mesmo diapasão do que afirmou Luciano de Camargo Penteado, Moacyr Lobo da Costa, em trabalho acerca da propriedade na doutrina de Duguit, ponderou que atribuir uma função social à propriedade não importa em transformá-la em tal função ou em confundi-la com esta. Entendia, com efeito, o autor de Três estudos sobre a doutrina de Duguit, que "a verdade ainda se encontra com a doutrina da Igreja", segundo a qual o direito de propriedade não dimana das leis humanas, mas da natureza, de modo que a propriedade não pode ser abolida pela autoridade pública, que, no entanto, pode moderar-lhe o uso e harmonizá-lo com o Bem Comum, como fez, com efeito, a Constituição Brasileira de $1946 .{ }^{46}$

Havendo feito menção, há pouco, aos nomes de Léon Duguit e de Santo Tomás de Aquino, julgamos ser mister salientar que o primeiro foi um grande e profundo admirador do último, tendo, em verdade, escrito que "a análise do sentimento de justiça foi feita por Santo Tomás de Aquino em termos nunca depois ultrapassados", ${ }^{47}$ do mesmo modo que reputamos ser relevante destacar que, como fez sentir Telga de Araújo, a própria defesa da função social da propriedade pelo célebre constitucionalista francês foi feita com base na noção tomista de Bem Comum. ${ }^{48}$

Posto isto, faz-se mister ressaltar que, caso compreendamos o conceito de função social da propriedade na "acepção clara de um dever do proprietário de atender à sua natural finalidade econômica e social com

\footnotetext{
${ }^{44}$ Direito das coisas, $2^{\mathrm{a}}$ edição revista, atualizada e ampliada, São Paulo, Editora Revista dos Tribunais, 2012, p. 215.

${ }^{45}$ Idem, pp. 215-216.

${ }^{46}$ A propriedade na doutrina de Duguit, in Três estudos sobre a doutrina de Duguit, São Paulo, Ícone Editora Limitada, 1997, p. 47.

${ }^{47}$ Traité de Droit Constitutionnel, $3^{\mathrm{a}}$ edição, tomo I, Paris, E. de Boccard, 1927, p. 122.

${ }^{48}$ Direito agrário - II, in Rubens Limongi FRANÇA (coordenador), Enciclopédia Saraiva de Direito, vol. 25, São Paulo, Saraiva, s/d, p. 198.
} 
vistas ao bem estar social", ${ }^{49}$ não poderemos deixar de concordar com Telga de Araújo quando este ressalta que a "tradicional doutrina católica" já cogitara da função social da propriedade muito antes de Duguit, "reconhecendo o elemento social da propriedade, a par do elemento individual". ${ }^{50}$ Esta é também, com efeito, a posição de Ballarín Marcial, que ponderou que "a verdadeira concepção tomista e cristã (...) foi sempre a de conceber o direito de propriedade ao serviço dos fins humanos, de funções individuais, familiares e sociais". 51

Ainda neste sentido, Moacyr Lobo da Costa, baseado em observação de Gaston Morin, ${ }^{52}$ escreveu, em estudo já aqui mencionado a respeito da propriedade na doutrina de Duguit, que a função social da propriedade já se encontra, sob terminologia um pouco diversa daquela de Comte e de Duguit, em Santo Tomás de Aquino, "para quem os bens apropriados individualmente têm um destino comum, que o homem deve absolutamente respeitar". 53

Santo Tomás de Aquino, com efeito, prelecionou, no Tratado da Justiça, na Suma Teológica, que o domínio sobre os bens, as coisas exteriores, concedido por Deus aos homens, deve estar sempre subordinado a um fim, que impõe a necessidade racional e social do bom uso de tais bens. ${ }^{54}$ De acordo com o Doutor Angélico, ao fazer uso de tais coisas, não deve a pessoa humana tê-las "como próprias, mas, como comuns, de modo que cada um as comunique facilmente aos outros, quando delas tiverem necessidade. ${ }^{55}$ Ainda de acordo com os ensinamentos do Aquinate, "qualquer bem da parte se ordena ao bem do todo". 56

49 Função social da propriedade, in Rubens Limongi FRANÇA (coordenador), Enciclopédia Saraiva do Direito, vol. 39. São Paulo, Saraiva, s/d, p. 7

${ }^{50}$ Idem, p. 5.

${ }^{51}$ Direito agrário, Volume 1, IBRA (Instituto Brasileiro de Reforma Agrária)/PUC, 1965, p. 7.

${ }^{52}$ L'œuvre de Duguit et le droit privé, in Archives de Philosophie du Droit et de Sociologie juridique, ns.1-2, Paris, Sirey, 1932, p. 158.

${ }^{53}$ A propriedade na doutrina de Duguit, in Três estudos sobre a doutrina de Duguit, São Paulo, Ícone Editora Limitada, 1997, p. 39.

${ }^{54}$ Cf. Gino ARIAS, Manual de Economía Política, Buenos Aires, L. Lajouane \& Cia. - Editores, 1942, p. 256.

${ }^{55}$ Santo Tomás de AQUINO, Suma Teológica, Segunda parte da segunda parte, questão 66, artigo $2^{\circ}$, solução, Tradução de Alexandre Corrêa, $1^{\text {a }}$ edição, vol. XIV, cit., p. 162.

56 Suma Teológica, Segunda parte da segunda parte, questão 58, artigo $5^{\circ}$, solução, Tradução de Alexandre Corrêa, $1^{\text {a }}$ edição, vol. XIV, cit., p. 28. 
Ao tratar desta passagem da Suma Teológica segundo a qual o homem não deve ter as coisas exteriores como próprias, senão como comuns, de maneira que cada um as comunique facilmente aos outros, quando delas necessitarem, afirmou Enríque Gil Robles que com tais palavras Santo Tomás sintetizou o "conceito cristão da propriedade", perfeita expressão "da caritativa solidariedade fraterna no campo do domínio". 57

Conforme enfatizou Heraldo Barbuy, as instituições medievais, de acordo com o pensamento de Santo Tomás de Aquino, afirmavam, por um lado, "o direito natural da propriedade" e, por outro, "a sua instrumentalidade, o fim social do seu uso", partindo do pressuposto de que "a propriedade, como instrumento de produção de riqueza, deve servir de meio à consecução dos fins para os quais a sociedade política se constitui, fins que se resumem no maior benefício da comunidade", enquanto o seu uso, a fim de "não violar os limites da moral natural, deve ser ordenado a esses fins: Jus utendi, non abutendi". ${ }^{58}$

Destarte, a doutrina cristã e tomista da propriedade, que, em suma, concebe a propriedade particular como uma propriedade individual em proveito de todos, ${ }^{59}$ se opõe tanto à inexistência de tal direito quanto à concepção absoluta deste. ${ }^{60}$

A concepção tomista da propriedade foi retomada pelo Papa Leão XIII, que, na Encíclica Rerum Novarum, de 1891, asseverou que a propriedade, fruto do trabalho humano, é um direito natural cujo uso deve estar subordinado ao Bem Comum, estando, pois, condicionado a um dever do proprietário, podendo o Estado regular-lhe o uso e conciliá-lo com o Bem Comum. ${ }^{61}$ Em tal Encíclica, o Sumo Pontífice não empregou a

${ }^{57}$ Tratado de Derecho Politico según los principios de la Filosofía y el Derecho Cristianos, tomo I, $3^{\mathrm{a}}$ edição, Nota preliminar de José María Gil Robles, Madrid, Afrodisio Aguado, S.A. Editores-Libreros, 1961, pp. 252253.

${ }^{58}$ A mobilização do solo e a instabilidade social, in Revista do Arquivo Municipal, Ano XVI, vol. CXXXII, São Paulo, Divisão do Arquivo Histórico do Departamento de Cultura da Secretaria de Educação e Cultura da Prefeitura de São Paulo, março de 1950, pp. 13-14.

${ }^{59}$ Cf. Friedrich SCHREYVOGL, Ausgewaehlte Schriften zur Staats - und Wirtschaftslehre des Thomas von Aquino, Jena, G. Fischer, 1923, p. 331.

${ }^{60}$ Cf. Alceu Amoroso LIMA, Introdução à Economia Moderna, $2^{\mathrm{a}}$ edição, Rio de Janeiro, Civilização Brasileira, 1933, p. 148.

61 Carta Encíclica Rerum Novarum, dada em Roma a 15 de maio de 1891. Disponível em: https://w2.vatican.va/content/leo-xiii/pt/encyclicals/documents/hf_1-xiii_enc_15051891_rerumnovarum.html. Acesso em 10 de agosto de 2019. 
expressão "função social", que apareceria pela primeira vez num documento pontifício no ano de 1931, na Encíclica Quadragesimo Anno, de Pio XI, ${ }^{62}$ mas, ao declarar que o direito de propriedade acarreta, para aquele que o exercita, um dever social imprescritível, efetivamente sustentou aquilo que hoje conhecemos como função social da propriedade. ${ }^{63}$

Neste mesmo diapasão, o já aqui mencionado economista italiano Francesco Vito, Reitor da Universidade Católica do Sagrado Coração de Milão, ao tratar da Carta Encíclica Rerum Novarum, sustentou que "a afirmação do direito de propriedade como sustentáculo econômico da pessoa humana" é acompanhada, no aludido documento, "da não menos vigorosa proclamação da função social da propriedade", função que se explica, antes e acima de tudo, "pelo cumprimento do dever da caridade a ser observado no uso da riqueza", riqueza esta que deve ser dirigida a fins produtivos quando acumulada, respeitando o seu proprietário, em suma, as limitações impostas pelo Estado com o intuito de "obter que os bens materiais sejam empregados de modo a resultar em vantagem de todos". ${ }^{64}$

Depois das encíclicas Rerum Novarum e Quadragesimo Anno, o princípio da função social da propriedade, que pode ser considerado um dos princípios fundamentais de toda a Doutrina Social da Igreja, foi novamente proclamado em diversas radiomensagens do Papa Pio XII, assim como em encíclicas como Mater et Magistra (1961) e Pacem in Terris (1963), de São João XXIII, Populorum Progressio (1967), de , e Laborem Exercens (1981), Sollicitudo Rei Socialis (1987) e Centesimus Annus (1991), de São João Paulo II, dentre outros documentos pontifícios.

A fundamental relevância da Igreja na elaboração do conceito de função social da propriedade tem sido assinalada por diversos juristas

\footnotetext{
${ }^{62}$ Carta Encíclica Quadragesimo Anno, dada em Roma a 15 de maio de 1931. Disponível em: https://w2.vatican.va/content/pius-xi/pt/encyclicals/documents/hf_p-xi_enc 19310515 quadragesimoanno.html. Acesso em 10 de agosto de 2019.

${ }^{63}$ Cf. Jean-Yves CALVEZ e Jacques PERRIN, Igreja e Sociedade Económica, Tradução de Agostinho Veloso, S.J., Porto, Livraria Tavares Martins, 1960, pp. 322-323.

${ }^{64}$ Transformações econômicas e doutrina social católica, in VV.AA., A encíclica Mater et Magistra e a hodierna questão social, Tradução de Carlos Ferrario, São Paulo, Edições Paulinas, 1962, pp. 16-17.
} 
patrícios, a exemplo de Telga de Araújo ${ }^{65}$ e Carlos Alberto Dabus Maluf, ${ }^{66}$ cumprindo salientar que, como acentuou o primeiro de tais jurisconsultos, a atuação dos pensadores católicos foi exercida justamente nos momentos mais críticos da marcha histórica do direito de propriedade, quando se fazia mister estabelecer limitações ao absolutismo de tal direito e ao individualismo, e mesmo às injustas arremetidas do Estado contra esse direito fundamental da pessoa humana. ${ }^{67}$

Dentre os diversos autores católicos que, antes de Léon Duguit, trataram do princípio da função social da propriedade, podemos destacar Enrique Gil Robles, que, no Tratado de Derecho Politico según los principios de la Filosofía y el Derecho Cristianos, cuja primeira edição data de 1899, a denominou "lei de solidariedade, ${ }^{68}$ e o Marquês de La Tour du Pin, que, em Vers un ordre social chrétien, de 1907, a chamou de "noção social". 69

Excetuando-se a há pouco aludida Carta del Carnaro, a primeira constituição jurídico-política escrita que não apenas consagrou a ideia de função social da propriedade como também empregou tal expressão foi a Constituição Portuguesa de 1933. Com efeito, o artigo 35 de tal Constituição determina que "a propriedade, o capital e o trabalho desempenham uma função social, em regime de cooperação económica e solidariedade, podendo a lei determinar as condições do seu emprego ou exploração conformes com a finalidade colectiva". Cumpre salientar, porém, que, diversamente da Carta del Carnaro, a Constituição Portuguesa de 1933 consagrou a concepção cristã e tomista da propriedade e não aquela positivista de Léon Duguit.

Em 1938, na Espanha nacionalista, o Foro do Trabalho (Fuero del Trabajo) assim estabeleceu, no título XII:

\footnotetext{
${ }^{65}$ Função social da propriedade, cit., p. 7.

${ }^{66}$ Cf. Carlos Alberto Dabus MALUF, Limitações ao direito de propriedade, $3^{\text {a }}$ edição revista e atualizada, Prefácio de Miguel Reale, São Paulo, Editora Revista dos Tribunais, 2011, p. 56.

${ }^{67}$ Função social da propriedade, cit., loc. cit.

${ }^{68}$ Tratado de Derecho Politico según los principios de la Filosofía y el Derecho Cristianos, tomo I, $3^{\mathrm{a}}$ edição, Nota preliminar de José María Gil Robles, Madrid, Afrodisio Aguado, S.A. Editores-Libreros, 1961, p. 258.

${ }^{69}$ Vers un ordre social chrétien: Jalons de route 1882-1907, $3^{\mathrm{a}}$ edição, Paris, Nouvelle Librairie nationale, s/d
} 
1. O Estado reconhece e ampara a propriedade privada como meio natural para o cumprimento das funções individuais, familiares e sociais.

Todas as formas de propriedade ficam subordinadas ao interesse supremo da Nação, cujo intérprete é o Estado.

2. O Estado assume a tarefa de multiplicar e tornar acessíveis a todos os espanhóis as formas de propriedade ligadas vitalmente à pessoa humana: o lar familiar, a herdade da terra e os instrumentos ou bens de trabalho para uso cotidiano.

A Constituição Italiana de 1947, por seu turno, assevera, em seu artigo 42, que "a propriedade privada é reconhecida pela lei, que determina as suas formas de aquisição, de posse e os limites, no intuito de assegurar a sua função social e de torná-la acessível a todos". Cinco anos antes, o Código Civil Italiano de 1942, ainda que não empregando a expressão "função social", já abandonara totalmente a concepção individualista de propriedade presente no Código Civil de 1865, o primeiro do Reino da Itália, também conhecido como Código Pisanelli.

Dois anos depois da Constituição Italiana, na então Alemanha Ocidental, a Lei Fundamental de Bonn reproduziu, com ligeiras alterações, no artigo 14, item 2, as há pouco citadas palavras da Constituição de Weimar a propósito da propriedade e das obrigações que esta acarreta ao seu detentor, tendo em vista o Bem Comum.

No Brasil, o princípio da função social da propriedade foi consagrado, ainda que sem tal nome, como vimos, nas Constituições de 1934 e 1946, e, já com este nome, como vimos há pouco, no Estatuto da Terra (Lei 4.504, de 30 de novembro de 1964), na Constituição de 1967 , na Emenda Constitucional $n^{\circ}$ 1, de 1969, na Constituição de 1988 e no Código Civil de 2002. É mister ressaltar, contudo, que, caso entendamos a função social da propriedade como o dever do proprietário de usar a propriedade de forma que esta cumpra os seus fins sociais e econômicos, servindo, assim, ao Bem Comum, não podemos deixar de julgar que, em verdade, tal princípio já se encontrava consagrado, em última instância, nas próprias Ordenações do Reino de Portugal ${ }^{70}$ e, antes delas, na Lei das

${ }^{70}$ Sobre as Ordenações do Reino Portugal: Ignacio Maria POVEDA VELASCO, Ordenações do Reino de Portugal, in Revista da Faculdade de Direito da USP, volume 89, São Paulo, 1994, pp. 11-67. 
Sesmarias, promulgada por El-Rei D. Fernando I de Portugal e do Algarve em 1375.

Neste sentido, escreveu Olavo Acyr de Lima Rocha que em todas as três Ordenações do Reino de Portugal refluem "as funções social e econômica da propriedade, em toda sua plenitude". ${ }^{71}$

A regra das Ordenações Filipinas segundo a qual os sesmeiros que não aproveitassem suas terras no prazo de um ano deveriam dá-las a quem as lavrasse e aproveitasse, havendo isto lugar "assi nos bens de quaesquer Grandes e Fidalgos, como de outros de qualquer condição que sejam", ${ }^{72}$ não era, contudo, válida no Império do Brasil, como ressaltou Teixeira de Freitas, na Consolidação das Leis Civis. ${ }^{73}$

É forçoso ressaltar que a Constituição Brasileira de 1934 poderia ter consagrado não apenas o princípio, mas também a expressão "função social", caso houvesse sido aprovada a redação do projeto de Constituição do Governo Provisório, de 1933, que sustentava que a propriedade tem, antes de tudo, "uma função social e não poderá ser exercida contra o interesse coletivo". Como enfatizou Moacyr Lobo da Costa, contudo, os constituintes preferiram não empregar tal expressão, adotando a redação mais neutra do item 17 do artigo $113,{ }^{74}$ segundo a qual o direito de propriedade não poderá ser exercido contra o "interesse social ou coletivo".

\footnotetext{
${ }^{71}$ As Ordenações Filipinas e o Direito Agrário, in Revista da Faculdade de Direito da Universidade de São Paulo, volume 95, São Paulo, jan./dez. 2000, p. 56.

${ }^{72}$ Codigo Philippino ou Ordenações e Leis do Reino de Portugal recopiladas por mandado d'El-Rey D. Philippe I, Livro IV, Título XLIII, § 1, $14^{a}$ edição, Introdução e notas de Cândido Mendes de Almeida, volume IV, Rio de Janeiro, Typographia do Instituto Philomathico, 1870, p. 823. Eis, na íntegra, tal parágrafo: §1 E os Sesmeiros que taes terras ou bens de sesmaria houverem de dar, saibão primeiro quaes são, ou foram os senhores delles. De como os souberem, façam os citar em pessoa, e suas mulheres, assinando-lhes tempo conveniente a que perante elles venham dizer, que razão tem a se não darem de sesmaria as ditas terras, casas ou pardieiros. E não abastará para isto terem citados os emphyteutas ou outros possuidores dos taes bens, mas todavia sejam citados os senhorios deles. Os quaes vindo à citação ouçamnos com as pessoas que as semarias requerem, e se taes causas allegarem e provarem, porque as não devam dar, não se darão. E se as não allegarem ou as não provarem, ou não vierem à dita citação assinemlhes hum anno (que he termo conveniente) para que as lavrem, ou aproveitem, e repairem os ditos bens, ou os vendão, emprazem, ou arrendem, a quem os possa aproveitar ou lavrar, E se o não fizerem, passado o dito anno, dêm os Sesmeiros as ditas sesmarias a quem as lavre e aproveite. E isto haverá lugar assi nos bens de quaesquer Grandes e Fidalgos, como de outros de qualquer condição que sejam."

${ }^{73}$ Consolidação das Leis Civis, terceira edição mais augmentada, Rio de Janeiro, 1876, volume 1, p. 61.

${ }^{74}$ A propriedade na doutrina de Duguit, in Três estudos sobre a doutrina de Duguit, São Paulo, Ícone Editora Limitada, 1997, p. 46.
} 
No ano de 1935, em conferência proferida em Fortaleza e intitulada A Constituição e o Código Civil, Clóvis Beviláqua reconheceu que “o conceito de propriedade" se apresentava neste "sob um cunho um tanto rígido, apesar da tentativa de o adaptar às exigências sociais", presente no projeto primitivo daquele diploma legal. A Constituição de 1934, todavia, ao afirmar que o direito de propriedade não pode ser exercido "contra o interesse social ou coletivo", adotou, no dizer do jurisconsulto cearense, "uma fórmula feliz", que atende, dentre outras coisas, "ao elemento individual" da propriedade, de cujos estímulos depende a prosperidade do agrupamento humano", e "ao elemento social", que, no entender de Beviláqua, se constitui na razão de ser e na finalidade do Direito. ${ }^{75}$

Promulgado aos 30 de novembro de 1964, pelo então Presidente da República, Marechal Humberto de Alencar Castello Branco, o Estatuto da Terra (Lei 4504/1964), considerado a lei agrária fundamental de nosso País, dispõe, no caput de seu artigo $2^{\circ}$, que "é assegurada a todos a oportunidade de acesso à propriedade da terra, condicionada pela sua função social, na forma prevista nesta Lei”. De acordo com o $\S 1^{\text {o do }}$ mesmo artigo, "a propriedade da terra desempenha integralmente a sua função social quando, simultaneamente": a) favorece o bem-estar dos seus proprietários e dos trabalhadores que nela labutam, bem como de suas famílias; b) mantém níveis de produção considerados satisfatórios; c) assegura a conservação dos recursos naturais; d) observa as disposições legais reguladoras das justas relações de trabalho entre os proprietários da terra e aqueles que a cultivam.

Como bem salientou Fernando Sodero, o Estatuto da Terra, em consonância com a Doutrina Social da Igreja, “mantém, integralmente, o princípio da propriedade privada da terra - em total oposição aos modelos socialistas". ${ }^{76}$ Com efeito, ainda como ressaltou Sodero, enquanto na Rússia bolchevista, por exemplo, a partir da promulgação do denominado Decreto da Terra, em outubro de 1917 , foi abolido o direito de propriedade

${ }^{75}$ A Constituição e o Código Civil, in Civililistica.com, ano 4, número 1, 2015, p. 4. Disponível em: http://civilistica.com/wp-content/uploads/2015/08/Bevil\%C3\%A1qua-civilistica.com-a.4.n.1.2015.pdf. Acesso em 10 de agosto de 2019.

${ }^{76}$, Direito agrário e reforma agrária, São Paulo, Livraria Legislação Brasileira, 1968, p. 98. 
privada, passando todas as terras para o domínio estatal, no Brasil, ao contrário, de acordo com os ensinamentos da Doutrina Social da Igreja, o poder público desejava "democratizar a propriedade, estabelecer o maior número possível de proprietários rurais". ${ }^{77}$

Isto posto, faz-se mister ressaltar que a função social da propriedade, compreendida de acordo com as preleções da Doutrina Social da Igreja, se constitui no principal princípio embasador do Estatuto da Terra, assim como num dos princípios fundamentais do Direito Agrário Pátrio, ao lado de outros como a Justiça Social, o fortalecimento da família, a ampliação do direito de propriedade, o desenvolvimento integral do rurícola, o estímulo à produção cooperativista e a ocupação e o desenvolvimento sustentável e ordenado da zona rural.

Objetivando, "antes e acima de tudo, a perfeita ordenação do Sistema agrário, de acordo com os princípios da justiça social, conciliando a liberdade de iniciativa com a valorização do trabalho humano" (artigo 103), o Estatuto da Terra, "grande obra de renovação", na expressão de Motta Maia, se constitui, segundo este autor, numa vitória tanto contra "o extremismo dos que desejariam a supressão pura e simples da propriedade privada" como contra o "radicalismo" daqueles que defendiam o status quo atual ao tempo de seu aparecimento, sem perceber que a difusão da terra significa o robustecimento da propriedade privada, ${ }^{78}$ uma vez que, como sustentou Rafael Gambra, os males da propriedade com mais propriedade se curam. ${ }^{79}$

Em 2002, foi promulgado o novo Código Civil Brasileiro, que, tratando da propriedade e de sua função social, assim dispõe, no $\S 1^{\circ}$ do artigo 1228:

O direito de propriedade deve ser exercido em consonância com as suas finalidades econômicas e sociais e de modo que sejam preservados, de conformidade com o estabelecido em lei especial,

\footnotetext{
${ }^{77}$ Idem, loc. cit.

${ }^{78}$ Explicação ao leitor, in Idem (Comentários e anotações), Estatuto da Terra, Rio de Janeiro, A. Coelho Branco Filho, Editor, 1965, p. XIII.

${ }^{79}$ La propiedad: sus bases antropológicas, in Verbo, números 181-182, Madrid, Speiro, ene.-feb., 1980 , p. 78.
} 
a flora, a fauna, as belezas naturais, o equilíbrio ecológico e o patrimônio histórico e artístico, bem como evitada a poluição do ar e das águas.

O parágrafo único do artigo 2035 do mesmo Código, por sua vez, determina que "nenhuma convenção prevalecerá se contrariar preceitos de ordem pública, tais como os estabelecidos por este Código para assegurar a função social da propriedade e dos contratos".

Assim, diversamente do Código Civil de 1916, também conhecido como Código Beviláqua, cujos aspectos individualistas foram expostos, dentre outros, por Lacerda de Almeida, ${ }^{80}$ o Código Civil de 2002, a que também podemos chamar de Código Miguel Reale, se orienta, como salientou este último, coordenador-geral da Comissão Revisora e Elaboradora de tal Código, pelo predomínio do social sobre o individual, visando, a um só tempo, "o bem individual e o bem comum". ${ }^{81}$

No primeiro capítulo da presente tese, discorreremos a respeito da Doutrina Social da Igreja, desde a Encíclica Rerum Novarum, de Leão XIII, até a Encílica Centesimus Annus, de São João Paulo II.

No segundo capítutulo, por seu turno, trataremos da propriedade e de sua função social à luz das preleções de Santo Tomás de Aquino e da Doutrina Social da Igreja.

Por fim, no terceiro e último capítulo desta tese, analisaremos a propriedade na Constituição Imperial de 1824 e em diferentes leis e projetos legislativos até o Código Civil de 2002 ou Código Miguel Reale, mostrando a evolução que teve, em tal período, o conceito de propriedade no Brasil e salientando o fundamental papel da Doutrina Social da Igreja nessa evolução.

${ }^{80}$ O Codigo Civil visto por alto; ou reparos criticos de doutrina a varias de suas disposiçóes mostrando o modo como foram tratadas no Codigo as differentes materias de que se occupa o Direito Civil, Rio de Janeiro, J. Ribeiro dos Santos, 1921.

${ }^{81}$ Visão geral sobre o novo Código Civil. Disponível em: http://www.miguelreale.com.br/artigos/vgpcc.htm. Acesso em 10 de agosto de 2019. 


\section{CONCLUSÃO}

Direito real por excelência e direito subjetivo padrão, a propriedade é, em última análise, a espinha dorsal não apenas do chamado Direito das Coisas, mas de todo o Direito Privado, assim como é um direito natural e fundamental da pessoa humana, que o Estado tem o dever de reconhecer e proteger.

Do mesmo modo, enquanto guardião do Bem Comum, tem o Estado a função de demarcar os limites da propriedade, função que, contudo, não pode desempenhar de modo arbitrário. Com efeito, não pode o poder público abolir a propriedade, mas pode e deve moderar-lhe o uso e harmonizá-lo com o Bem Social.

Salvaguarda da liberdade e do estímulo ao trabalho, a propriedade possui um duplo caráter individual e social, e, portanto, deve servir às necessidades do proprietário e também ao Bem Comum, cumprindo sublinhar que esse duplo caráter não a enfraquece, mas, ao contrário, a robustece. Em outros termos, como tivemos ocasião de afirmar, a propriedade, ao se libertar dos princípios do individualismo, tende a se fortalecer, tornando-se cada vez menos atacável em nome do princípio da Justiça Social.

Como restou dito, toda vez que se nega ou atenua o caráter social da propriedade, cai-se no erro do individualismo, da mesma forma que quando se nega ou atenua o caráter individual da mesma propriedade se incorre no erro do coletivismo.

Conforme preleciona a Doutrina Social da Igreja e diversamente do que proclamam os positivistas e alguns socialistas, a propriedade tem uma função social, assim como tem uma função individual e uma função familiar, e não é uma função social. Em outros termos, a propriedade possui uma função social, posto que está subordinada ao Bem Comum, sendo um direito que comporta deveres a seu detentor, mas não uma função social. 
Consoante ressaltamos no presente trabalho, foi a concepção da propriedade e de sua função social sustentada pela Doutrina Social Católica aquela consagrada pelo ordenamento jurídico pátrio e não aquela da propriedade-função, que tem em Léon Duguit seu máximo expoente e caiu no erro de negar o direito de propriedade.

Se os defensores da teoria da propriedade-função incorreram no erro de ver tão somente o elemento social da propriedade, os individualistas dos séculos XVIII e XIX e dos primeiros anos do século XX incorreram no equívoco de nela enxergar apenas o caráter individual.

Como observamos, após um longo período de predomínio do mais radical individualismo jurídico, que concebeu a propriedade como um direito absoluto e oposto ao Bem Comum e que talvez jamais tenha tido uma expressão legislativa plena, assim como jamais sustentou a verdadeira concepção romana do direito de propriedade, tem imperado, desde o ocaso da I Guerra Mundial, uma nova e mais justa concepção de propriedade, que, corresponde, em última instância, à concepção tomista e cristã da propriedade. Destarte, as legislações foram impondo justas restrições ao direito de propriedade e o uso desta passou a ser subordinado ao interesse público, de forma que o social sobrepujou o individual, não para destruílo, mas sim para salvaguardar a dignidade da pessoa humana.

Conforme também sublinhamos, a Doutrina Social da Igreja exerceu profunda influência sobre os pensadores e as legislações do período que se seguiu ao término do aludido conflito global, tendo, em outras palavras, desempenhado tal doutrina um papel fundamental no advento da era de primazia do social que então se inaugurou no Ocidente, sobre as ruínas da idade individualista-liberal que tivera seu apogeu no século XIX.

Tal como foi dito, o Brasil não ficou alheio a esse movimento de ideias que restaurou o primado do social sobre o individual. Com efeito, se até fins do primeiro quartel do século XX o direito positivo pátrio seguiu, em larga medida, os cânones do individualismo jurídico, que inspirou, dentre outros diplomas legais, as constituições de 1824 e de 1891 , assim como o Código Civil de 1916, já no crepúsculo dos anos 1910 não eram poucas as vozes que se erguiam, em nosso País, contra tal 
individualismo, muitas delas inspiradas pelos ensinamentos da Doutrina Social da Igreja, cujo influxo se faria notar em toda a regulação do direito de propriedade a partir da Constituição de 1934.

Primeiro diploma legal pátrio a não apenas consagrar o princípio da função social da propriedade, como também a empregar tal expressão, o Estatuto da Terra (Lei 4.504, de 30 de novembro de 1964) é, provavelmente, o documento legislativo nacional em que se faz mais notável esse influxo da Doutrina Social da Igreja sobre o direito de propriedade em terras brasileiras.

Encerremos este trabalho. A propriedade particular deve ser uma propriedade individual a serviço de todos e deve ser, ademais, difundida ao máximo. A propósito, em nosso sentir, os problemas da propriedade se resolvem, antes de tudo, com mais propriedade, isto é, com a ampla disseminação do direito de propriedade, somada ao cumprimento de sua função social. 


\section{BIBLIOGRAFIA :}

ACKER, Leonardo Van, Influência e metamorfoses da "Cidade de Deus" de Aurélio Agostinho, in Revista Brasileira de Filosofia, Volume 4, Número 4, out./dez. de 1954, pp. 501-519;

ACQUAVIVA, Marcus Claudio, Teoria Geral do Estado, 2a edição, revista e aumentada, São Paulo, Editora Saraiva, 2000;

AgOSTINHO, Santo, O livre-arbítrio, Tradução, organização, introdução e notas de Nair Assis Oliveira, Revisão de Honório Dalbosco, São Paulo, Paulus, 1995;

AHRENS, Heinrich, Cours de Droit Naturel ou de Philosophie du Droit, $4^{\mathrm{a}}$ edição, Bruxelles, Meline, Cans \& Ce., 1853;

ALENCAR, José de, A Propriedade, Com uma prefação do Exmo. Sr. Conselheiro Dr. Antonio Joaquim Ribas, Rio de Janeiro, B. L. Garnier - Livreiro Editor, 1883;

, Esboços Jurídicos, Rio de Janeiro, B.L. Garnier - Livreiro

Editor, 1883;

ALMEIDA, Francisco de Paula Lacerda de, O Codigo Civil visto por alto; ou reparos criticos de doutrina a varias de suas disposições mostrando o modo como foram tratadas no Codigo as differentes materias de que se occupa o Direito Civil, Rio de Janeiro, J. Ribeiro dos Santos, 1921;

, Direito das cousas: Exposição

systemtica desta parte do Direito Civil Patrio, Rio de Janeiro, J. Ribeiro dos Santos-Livreiro-Editor, 1908;

ALVES, José Carlos Moreira ALVES, Direito Romano, 6 a edição, Rio de Janeiro, Forense, 1987, volume 1;

AMEAL, João, São Tomaz de Aquino: Iniciação ao estudo da sua figura e da sua obra, $3^{\text {a }}$ edição, revista e acrescida, com novos apêndices e um quadro biobibliográfico, Porto, Livraria Tavares Martins, 1947;

A revolução tomista, Braga, Livraria Cruz, 1952; 
ANTÓNIO, Santo, Obras completas, Lisboa, Editorial Restauração, 1970, Volume 3;

AQUINO, Santo Tomás de, Suma Teológica, Segunda parte da segunda parte, questões LVII-LXXIX, Tradução de Alexandre Corrêa, 1ª edição, vol. XIV, São Paulo, Livraria Editora Odeon, 1937;

, Suma Teológica, Segunda parte da segunda parte, questões XLVII-LVI, Tradução de Alexandre Corrêa, Organização de Rovílio Costa e Luís Alberto De Boni, Introdução de Martin Grabmann, 2a edição, volume V, Porto Alegre, Escola Superior de Teologia São Lourenço de Brindes, Livraria Sulina Editora; Caxias do Sul, Universidade de Caxias do Sul, 1980;

, Summa Theologiae, com comentários do Cardeal Tomás de Vio (Caetano), in Opera Omnia iussu Leonis XIII P. M. Edita, Tomos 4 a 12, Roma, Commissio Leonina, 1888-1906;

, Do governo dos príncipes ao Rei de Cipro, in SANTOS, Arlindo Veiga dos (Org. e trad.), Filosofia política de Santo Tomás de Aquino, $3^{\mathrm{a}}$ edição, melhorada, Prefácio do Prof. Dr. L. Van Acker, São Paulo, José Bushatsky, Editor, 1956, pp. 21-185;

, Sententia Libri Politicorum, in Opera Omnia iussu Leonis XIII P. M. Edita, Tomo 48, Roma, Commissio Leonina, 1971; , Commento all'Etica Nicomachea, volume I, Tradução italiana de Lorenzo Perotto, Bologna, Edizioni Studio Domenicano, 1998;

ARAÚJO, Telga de, Direito agrário - II, in FRANÇA, Rubens Limongi (coord.), Enciclopédia Saraiva do Direito, vol. 25, São Paulo: Saraiva, s/d., pp. 197-207;

, Função social da propriedade, in FRANÇA, Rubens Limongi (coord.), Enciclopédia Saraiva do Direito, vol. 39, São Paulo, Saraiva, s/d, pp. 1-16;

ARDANT, Gabriel, Papi e contadini, Tradução italiana de Luigi Masson, Siena, San Bernardino, 1895; 
ARIAS, Gino, Manual de Economía Política, Buenos Aires, L. Lajouane \& Cia. - Editores, 1942;

, Corso di Economia Corporativa, $2^{\mathrm{a}}$ edição, Roma, Società Editrice del Foro italiano, 1937;

, La Filosofia Tomistica e l'Economia Politica, Milano, Vita e Pensiero, 1934;

, Le stituzioni giuridiche medievali nella Divina Commedia, Firenze, F. Lumachi, 1901;

ARISTÓTELES, Política (edição bilíngue), Tradução de António Campelo Amaral e Carlos Gomes, Lisboa, Vega, 1998;

Ética a Nicômaco, Tradução de Edson Bini, $3^{\text {a }}$ edição, Bauru, SP, EDIPRO, 2009;

, Retórica, Livro I, 13, Tradução de Edson Bini, $1^{\mathrm{a}}$ edição, BAURU, SP, EDIPRO, 2011;

, Retórica, Tradução de Edson Bini, $1^{\mathrm{a}}$ edição, BAURU, SP, EDIPRO, 2011;

ÁVILA, Fernando Bastos de, Pequena enciclopédia de Doutrina Social da Igreja, São Paulo, Edições Loyola, 1991;

O pensamento social cristão antes de Marx:

Textos e comentários, Rio de Janeiro, José Olympio Editora, 1972;

AZAMBUJA, Darcy, Teoria Geral do Estado, $38^{\mathrm{a}}$ edição, São Paulo, Globo, 1998;

AZEVEDO, Álvaro Villaça, Bem de família (com comentários à Lei 8.009/90), São Paulo, Editora Revista dos Tribunais, 2002; , Curso de Direito Civil, volume 5: Direito das Coisas, $1^{\mathrm{a}}$ edição, São Paulo, Atlas, 2014;

BALEEIRO, Aliomar, 1891 (Coleção Constituições Brasileiras, Volume 2), $3^{a}$ edição, Brasília, Senado Federal, Subsecretaria de Edições Técnicas, 2012; 
BALLARÍN MARCIAL, Alberto, Derecho Agrario, 2a edição, Madrid, Editorial Revista de Derecho Privado, 1978.

, Direito agrário, volume 1, IBRA

(Instituto Brasileiro de Reforma Agrária)/PUC, 1965;

BARBOSA, Rui, A questão social e política no Brasil, in Obras completas de Rui Barbosa, volume XLVI, (1919), Tomo I (Campanha presidencial), Rio de Janeiro, Ministério da Educação e Cultura, 1941, pp. 62-130;

BARBUY, Heraldo, A mobilização do solo e a instabilidade social, in Revista do Arquivo Municipal, Ano XVI, volume CXXXII, São Paulo, Divisão do Arquivo Histórico do Departamento de Cultura da Secretaria de Educação e Cultura da Prefeitura de São Paulo, mar. de 1950, pp. 13-32; , Noção do justo preço, in Reconquista, volume I, n² 2, São Paulo, 1950, pp. 140-143;

, Não se fabrica uma sociedade, in Reconquista, ano I, $\mathrm{n}^{\circ}$ 12, São Paulo, maio de 1953, p. 1;

- Sumo bem e suma riqueza. Separata do Anuário da Faculdade de Filosofia "Sedes Sapientiae”, da Universidade Católica de São Paulo, 1953;

, A Família e a Sociedade, in Servir, $\mathrm{n}^{\circ} 1297$, ano XXVII, São Paulo, 20 de setembro de 1957, pp. 75 e 77;

BARBUY, Victor Emanuel Vilela, Justiça e Bem Comum, in Marcelo Roland ZOVICO (Organizador), Filosofia do Direito: Estudos em homenagem a Willis Santiago Guerra Filho, São Paulo, Editora Clássica, 2012, p. 316-342;

Aspectos do Direito na obra de Santo Tomás de Aquino, in Revista da Faculdade de Direito, Volume 106/107, São Paulo, Universidade de São Paulo, 2011/2012, pp. 631-651;

, Notas sobre a Tradição, in Revista do Instituto Histórico e Geográfico de São Paulo, Ano CXXII, Volume C, São Paulo, 2016, pp. 191-203; 
, Idealismo utópico e idealismo orgânico em Oliveira Vianna, in Revista de Geopolítica, Volume 9, N. 2, jul./dez. 2018, pp. 157-172; , Aspectos do Distributismo no Brasil, in Revista de Geopolítica, Volume 10, N. 1, jan./jun. 2019, pp. 45-59; , Município e Municipalismo no Brasil. In Revista de Geopolítica, Volume 9, N. 1, Natal, jan./jun. 2018, pp. 143-152; , Ideias jurídicas de José de Alencar, Dissertação de Mestrado defendida em 09 de junho de 2014 na Faculdade de Direito da Universidade de São Paulo;

BARROS, Wellington Pacheco, Curso de Direito Agrário, volume 1, $3^{\mathrm{a}}$ edição, revista e ampliada, Porto Alegre, Livraria do Advogado, 1998;

BASTOS, Celso Ribeiro, e MARTINS, Ives Gandra, Comentários à Constituição do Brasil, São Paulo, Saraiva, 1989;

BATALHA, Wilson de Souza Campos, Loteamentos e condomínios, tomo I, São Paulo, Max Limonad, 1953;

BELlOC, Hilaire, O Estado servil, Tradução de Talles Diniz Tonatto, Curitiba, Livraria Danúbio Editora, 2017; An Essay on the Restoration of Property, Norfolk, HIS Press, 2002;

BEVILÁQUA, Clóvis, Direito das Coisas, vol. I, 5a edição atualizada por José Aguiar Dias, Rio de Janeiro, Forense, 1961;

, A Constituição e o Código Civil, in Civililistica.com, ano 4, número 1, 2015, p. 4. Disponível em: http://civilistica.com/wpcontent/uploads/2015/08/Bevil\%C3\%A1qua-civilistica.com-

a.4.n.1.2015.pdf. Acesso em 10 de agosto de 2019;

BERDIAEFF, Nikolai, De l'esprit bourgeois, Tradução francesa de Elisabeth Bellençon, Paris, Delachaux et Niestlé S. A, 1949;

BigotTe-ChORÃO, Mário, Pessoa Humana e Bem Comum como princípios fundamentais da Doutrina Social da Igreja: Subsídios para uma 
revisão da cultura dominante, Lisboa, Universidade Católica Portuguesa, 1994;

BOEHNER, Philotheus e GILSON, Étienne, História da Filosofia Cristã, $9^{\text {a }}$ edição, Petrópolis, Vozes, 2004;

BORGES, Paulo Torminn, Institutos Básicos de direito agrário, $6^{\mathbf{a}}$ edição, rev. e ampliada, São Paulo, Saraiva, 1991;

BRAGUE, Rémi, A Lei de Deus: História filosófica de uma aliança, Tradução de Armando Pereira da Silva, Lisboa, Instituto Piaget, 2008;

BRASIL, Annaes da Assembléa Nacional Constituinte (1933/1934), Rio de Janeiro, Imprensa Nacional, 1934-1937 (22 volumes);

BRUCCULERI SJ, Angelo, A função social da propriedade, Tradução portuguesa, Porto, Livraria Apostolado da Imprensa, 1956;

O Estado e o indivíduo, Tradução de Luís Leal Ferreira,

Rio de Janeiro, Livraria AGIR Editora, 1948;

BUENo, José Antonio Pimenta (Marquês de São Vicente), Direito Publico Brazileiro, e Analyse da Constituição do Imperio, $1^{\mathrm{a}}$ edição, Rio de Janeiro, Typographia Imperial e Constitucional de J. Villeneuve \& Cia, 1857 ;

BUZAID, Alfredo, Humanismo político (conferência proferida em 6 de julho de 1973, na Escola Superior de Guerra), Rio de Janeiro, Ministério da Justiça, 1973;

Camões e o Renascimento, São Paulo, Saraiva, 1984;

Da ação renovatória (de contrato de locação de imóveis destinados a fins comerciais), $1^{\text {a }}$ edição, São Paulo, Saraiva, 1958;

Rui e a questão social, in Rui Barbosa processualista civil e outros estudos, São Paulo, Saraiva, 1989, pp. 69-101;

Ensaios literários e históricos, São Paulo, Editora

Saraiva, 1983;

CAETANO, Marcello, História do Direito Português (séculos XII-XVI), seguida de Subsídios para a História das fontes do Direito em Portugal no 
século XVI, $4^{\mathrm{a}}$ edição, Textos introdutórios e notas de Nuno Espinosa Gomes da Silva, Lisboa, Editorial Verbo, 2000;

CALDERÓN BOUCHET, Rubén, Formación, apogeo y decadencia de la ciudad cristiana, $1^{\text {a }}$ edição, Buenos Aires, Dictio, 1979;

El espíritu del capitalismo, $1^{\mathrm{a}}$ edição, Buenos Aires, Nueva Hispanidad, 2008;

CALVEZ, Jean-Yves e PERRIN, Jacques, Igreja e Sociedade Económica: O ensino social dos papas de Leão XIII e Pio XII (1878-1958), Tradução de Agostinho Veloso, S.J., Porto, Livraria Tavares Martins, 1960;

CARDOSO, Malta, Tratado de Direito Rural Brasileiro, vol. I, São Paulo, Edições Saraiva, 1953;

Constituições do Brasil, Compilação e atual. dos textos, notas, rev. e índices por Adriano Campanhole e Hilton Lobo Campanhole, 9a edição, São Paulo, Editora Atlas, 1987;

CARVALHO, José Baptista de, A verdadeira história das capitanias hereditárias, Prefácio de Hernâni Donato, São Paulo, Sem editora, 2008;

CASTÁN TOBEÑAS, José, Familia y propiedad: La propiedad familiar en la esfera civil y en la del Derecho Agrario, Madrid, Instituto Editorial Reus, 1956;

La propiedad y sus problemas actuales, $2^{\mathrm{a}}$ edição revisada e ampliada, Madrid, Editorial Reus, 1963;

CASTro, Raimundo Araújo, A Constituição de 1937, $3^{\text {a }}$ edição, Brasília, Senado Federal, 2003;

CATHREIN, Viktor, Filosofía Morale, volume II, Tradução italiana, Firenze, Libreria Editrice Fiorentina, 1913;

CAVAllerA, Ferdinand, Précis de la Doctrine Sociale Catholique, nouvelle édition mise à jour, Paris, Action Populaire; Éditions SPES, 1937 ;

CESARINO JUNIOR, Antônio Ferreira, Direito Social, São Paulo, LTr; Editora da Universidade de São Paulo, 1980; 
CÍCERO, Marco Túlio, De Legibus. Disponível em: http://www.thelatinlibrary.com/cicero/leg.shtml. Acesso em 5 de agosto de 2019;

De Inventione. Disponível em: http://www.thelatinlibrary.com/cicero/inventione.shtml. Acesso em 5 de agosto de 2019;

Dos deveres, Tradução e notas de João Mendes Neto, São Paulo, Saraiva, 1965;

CHAVES, René Penna, Estudo da significação e função dos Municípios e das Câmaras Municipais, Campinas, Oficinas Gráficas "Casa Livro Azul”, 1949;

CHESTERTON, Gilbert Keith, O que há de errado com o mundo, Tradução de Luíza Monteiro de Castro Silva, Campinas, Ecclesiae, 2013;

Um esboço da sanidade: pequeno manual do distributismo, Tradução e notas de Raul Martins, Campinas, Ecclesiae, 2016;

COLOGNESI. Luigi Capogrossi, Proprietà (Diritto Romano), in Enciclopedia del Diritto, Milano, Giuffrè, 1988, volume 37, pp. 189 e ss.; COMTE, Auguste, Cours de Philosophie Positive, tomo quarto, Paris, Bachelieur, Imprimeur-Libraire, 1839; , Système de politique positive ou Traité de Sociologie, instituant la Religion de l'Humanité, Tomo I, Paris, Librairie ScientifiqueIndustrielle de L. Mathias, 1852;

COPLESTON, Frederick, Filosofia Medieval: Uma introdução, Tradução de Wilson Filho Ribeiro de Almeida, Curitiba, Livraria Danúbio Editora, 2017

History of Philosophy, Volume IX, New York, Image Books/Doubleday, 1994; 
CORRÊA, Alexandre, Concepção tomista do Direito Natural (1941), in Ensaios políticos e filosóficos, Prefácio de Ubiratan Macedo, São Paulo, Editora Convívio/EDUSP, 1984, pp. 141-250;

COSTA, Mário Júlio de Almeida, História do Direito português, $3^{\text {a }}$ edição, $2^{\mathrm{a}}$ reimpressão, Coimbra, Almedina, 2000;

COSTA, Moacyr Lobo da, A propriedade na doutrina de Duguit, in Três estudos sobre a doutrina de Duguit, São Paulo, Ícone Editora Limitada, 1997, pp. 27-47;

COTRIM NETO, Alberto, Curso de doutrina dos socialismos, Rio de Janeiro, Livraria Freitas Bastos, 1953; , Fontes do corporativismo moderno, in Cadernos da Hora Presente, ${ }^{\circ}$ 5, São Paulo, out. de 1939, pp. 7-26;

COUTO, Rui Ribeiro, Entre mar e rio, $3^{\mathrm{a}}$ edição, in Poesias reunidas, Rio de Janeiro, José Olympio Editora, 1960;

DABIN, Jean, Le Droit subjectif, Paris, Dalloz, 1952;

DANTAS, Francisco Clementino de San Tiago, Programa de Direito Civil, III, Revisão de texto e anotações de João Gomes de Bezerra Câmara, 2a edição, Rio de Janeiro, Editora Rio, 1981;

DERISI, Octavio Nicolás, Valores essenciais para a construção de uma sociedade realmente humana, Tradução de Alfredo Augusto Rabello Leite, São Paulo, Brasil, Mundo Cultural, 1977;

DAWSON, Christopher, A formação da Cristandade, Tradução de Márcia Xavier de Brito, São Paulo, É Realizações, 2014;

A criação do Ocidente: A Religião e a Civilização Medieval, Tradução e apresentação de Maurício G. Righi, São Paulo, É Realizações, 2016;

D’AZEGLIO, Luigi Taparelli, Saggio teoretico di Diritto Naturale appoggiato sul fato, Livorno, Vincenzo Mansi Editora, 1843; 
DAWSON, Christopher, A criação do Ocidente: A Religião e a Civilização Medieval, Tradução e apresentação de Maurício G. Righi, São Paulo, É Realizações, 2016;

DEFROIDMONT, Jean. La Science du Droit Positif. Paris, D. de Brouwer, 1933 ;

DI MARZO, Salvatore, Proprietà (Diritto Romano), in Nuovo Digesto Italiano, Torino, UTET, 1939, volume 17, pp. 670 e ss.;

DINIZ, Maria Helena, Curso de Direito Civil Brasileiro, volume 4: Direito das Coisas, 26 a edição, São Paulo, Editora Saraiva, 2011;

DUGUIT, Léon, Traité de droit constitutionnel, $3^{\mathrm{a}}$ edição, tom. I, Paris, E. de Boccard, 1927;

,Manuel de droit constitutionnel, $2^{\mathrm{a}}$ ed. Paris, De Boccarel,

1911;

FABRO, Cornelio, Breve introduzione al tomismo, Roma, Desclée, 1960;

FAGUNDES, Miguel Seabra, Da ordem econômica na nova Constituição, in Themistocles Brandão CAVALCANTI e outros, Estudos sobre a Constituição de 1967, Rio de Janeiro, Fundação Getúlio Vargas, 1968, pp. 159-173.

FANFANI, Amintore, Storia delle dottrine economiche. Il volontarismo, $3^{\mathrm{a}}$ edição, Milano, Casa Editrice Giuseppe Principato, 1942;

FANTINI, Oddone, Trattato di Politica Economica e Finanziaria, Milano, Società Editrice Libraria, 1939;

FERREIRA, Jacinto, No debate das ideias, Lisboa, qp, 1973;

Poder local e corpos intermédios, Lisboa, Edições

Cultura Monárquica, 1987;

FERREIRA, Pinto, Curso de Direito Agrário, $3^{\mathrm{a}}$ edição rev. e atual., São Paulo, Saraiva, 1998;

FERREIRA, Waldemar, História do Direito Brasileiro, Volume 1 (As capitanias coloniais de juro e herdade), $2^{a}$ edição, São Paulo, Saraiva, 1962; 
O conteúdo econômico da constituição brasileira de 1946, in Revista da Faculdade de Direito de São Paulo, Volume 43, São Paulo, 1948, pp. 91-112;

FERREIRA FILHO, Manoel Gonçalves, Comentários à Constituição Brasileira de 1988, $1^{a}$ edição, volume 1, São Paulo, Saraiva, 1990;

FLEIUSS, Max, História administrativa do Brasil, $2^{\text {a }}$ edição, São Paulo, Companhia Melhoramentos de São Paulo, 1922;

FRANCA, SJ, Padre Leonel, Cristianismo e Democracia, in Obras completas do Padre Leonel Franca, Volume V, Alocuções e artigos, Tomo I, Rio de Janeiro, Livraria AGIR Editora, 1954;

FREITAS, Augusto Teixeira de, Consolidação das Leis Civis, terceira edição mais augmentada, Rio de Janeiro, 1876; , Código Civil: Esboço, Rio de Janeiro, Ministério da Justiça e Negócios Interiores, 1952;

FREYRE, Gilberto, O mundo que o português criou, $1^{\text {a }}$ edição, Rio de Janeiro, José Olympio Editora, 1940;

FULGÊNCIO, Tito, Direitos de vizinhança: limites de prédios, Rio de Janeiro, Forense, 1959;

GARRIGOU-LAGRANGE, Réginald, La síntesis tomista, Tradução de Eugenio Melo, Buenos Aires, Ediciones Desclée, De Brouwer, 1946;

GARRIGUET, Louis, La propriété privée, Paris, Librairie Bloud et Cie., 1909;

GENTILE, Giovanni, Individuo e Stato o la corporazione proprietaria, in Educazione fascista, agosto 1932, pp. 635-638;

GESTEL, Constant van, A Igreja e a Questão Social, Tradução e adaptação do Padre Fernando Bastos de Ávila, Rio de Janeiro, Livraria Agir Editora, 1956;

GAMBRA, Rafael, La propiedad: sus bases antropologicas, in Verbo, números 181-182, Madrid, Speiro, ene-feb 1980, pp. 75-82; 
GIDE, Charles, El marxismo, in Idem e Charles Rist, Historia de las doctrinas económicas, Volume II (De la Escuela Histórica a John Maynard Keynes), Tradução castelhana de Carlos M. Giuliani Fonrouge, Buenos Aires, Editorial Depalma, 1949, pp. 627-669;

Compêndio d'Economia Política, Traduzido com licença do autor, prefaciado e adaptado ao Brasil por Félix Contreiras Rodrigues, 12 ${ }^{\mathrm{a}}$ edição, Porto Alegre, Globo, 1953;

GIL ROBLES, Enrique, Tratado de Derecho Político según los principios de la Filosofía y el Derecho Cristianos, tomo I, $3^{\text {a }}$ edição, Nota preliminar de José María Gil Robles, Madrid, Afrodisio Aguado, S.A. EditoresLibreros, 1961;

GILSON, Étienne, Le thomisme: Introduction à la philosophie de Saint Thomas d'Aquin, 5 a edição, revista e aumentada, Paris, J. Vrin, 1947;

O espírito da Filosofia Medieval, Tradução de Eduardo Brandão, São Paulo, Martins Fontes, 2006;

A Filosofia na Idade Média, Tradução de Eduardo Brandão, $1^{\text {a }}$ edição, $3^{\text {a }}$ tiragem, São Paulo, Martins Fontes, 2001;

GIMÉNEZ LANDÍNEZ, Víctor Manuel, Hacia la Declaración de los Derechos del Campesino, Caracas, Ministerio de Agricultura y Cria, 1961; GOMES, Alfredo, Introdução à Economia: Subsídios históricos e doutrinários, Rio de Janeiro, Livraria AGIR Editora, 1958;

GOMES, Orlando, Direitos Reais, $19^{\mathrm{a}}$ edição, revista, atualizada e aumentada de acordo com o Código Civil de 2002 (Atualizador: Luiz Edson Fachin, Coordenador: Edvaldo Brito), Rio de Janeiro, Forense, 2005;

GOMES, Perillo, O liberalismo, Prefácio de Tristão de Athayde (Alceu g GRATRY, Abbé Alphonse, Catéchisme social, ou demandes et réponses sur les devoirs sociaux, Paris, Librairie de Gaume frères, 1848;

GRAU, Eros Roberto, A ordem econômica na Constituição de 1988, $4^{\mathrm{a}}$ edição, revista e atualizada, São Paulo, Malheiros, 1997; 
GUERRY, Monsenhor Émile, A Doutrina Social da Igreja, Lisboa, Livraria Sampedro, 1960;

GUTIÉRREZ GARCÍA, José Luis (Organizador), Doctrina Pontificia II: Documentos Políticos, Madrid, Biblioteca de Autores Cristianos (BAC), 1958 ;

HerCulano, Alexandre, História de Portugal, $8^{\mathrm{a}}$ edição, Paris; Lisboa, Livrarias Aillaud \& Bertrand; Rio de Janeiro, Francisco Alves, s/d, tomo VII;

HERVADA, Javier, Lições propedêuticas de Filosofia do Direito, Tradução de Elza Maria Gasparotto, Revisão técnica de Gilberto Callado de Oliveira, São Paulo, WMF Martins Fontes, 2008;

HUGON, Padre Édouard, Os princípios da filosofia de São Tomás de Aquino: as vinte e quatro teses fundamentais, Tradução de D. Odilão Moura, Porto Alegre, EDIPUCRS, 1998;

HUGON, Paul, História das doutrinas econômicas, $8^{\text {a }}$ edição, São Paulo, Editora Atlas, 1966;

IBÁÑEZ LANGLOIS, José Miguel, Doutrina Social da Igreja, Tradução de Maria da Graça de Mariz Rozeira, 2a edição, Lisboa, Rei dos Livros, 1994;

INSTITUTO DE PESQUISAS E ESTUDOS SOCIAIS (IPÊS), A reforma agrária: Problemas, bases, solução, São Paulo, IPÊS, 1964;

JAEGER, Werner, Cristianismo primitivo y Paideia griega, Tradução castelhana de Elsa Cecilia Frost, $1^{\text {a }}$ edição, México, Fondo de Cultura Económica, 1965;

JARRETT, Bede, S. Antonino and Medieval Economics, London, B. Herder, 1914 ;

JHERING, Rudolf von, A evolução do Direito, Tradução de Abel D’Azevedo, Lisboa, José Bastos \& Cia., s/d;

JOÃO XXIII, São, Carta Encíclica Mater et Magistra, dada em Roma aos 15 de maio de 1961. Disponível em: http://w2.vatican.va/content/john- 
xxiii/pt/encyclicals/documents/hf_j-xxiii_enc_15051961_mater.html. Acesso em 10 de agosto de 2019;

, Carta Encíclica Pacem in Terris, dada em Roma aos

11 de abril de 1963. Disponível em: http://w2.vatican.va/content/johnxxiii/pt/encyclicals/documents/hf_j-xxiii_enc_11041963_pacem.html.

Acesso em 10 de agosto de 2019;

JOÃO PAULO II, São, Carta Encíclica Laborem Exercens, dada em Castel Gandolfo aos 14 de setembro de 1981. Disponível em: http://w2.vatican.va/content/john-paul-ii/pt/encyclicals/documents/hf_jpii_enc_14091981_laborem-exercens.html. Acesso em 10 de agosto de 2019 ;

, Carta Encíclica Sollicitudo Rei Socialis, dada em Roma aos 30 de dezembro de 1987. Disponível em: http://w2.vatican.va/content/john-paul-ii/pt/encyclicals/documents/hf_jpii_enc_30121987_sollicitudo-rei-socialis.html\#\%2427. Acesso em 10 de agosto de 2019;

, Discurso do Papa João Paulo II na solene sessão de abertura da III Conferência Geral do Episcopado Latino-Americano, Puebla de los Ángeles, 28 de janeiro de 1979. Disponível em: http://w2.vatican.va/content/john-paulii/pt/speeches/1979/january/documents/hf_jp-ii_spe_19790128_messicopuebla-episc-latam.html. Acesso em 5 de agosto de 2019;

, Carta Encíclica Centesimus Annus, dada em Roma a $1^{\circ}$ de maio de 1991. Disponível em: http://www.vatican.va/content/johnpaul-ii/pt/encyclicals/documents/hf_jp-ii_enc_01051991_centesimusannus.html. Acesso em 10 agosto de 2019;

JOSSERAND, Louis, Cours de Droit Civil Positif Français: Conforme aux programmes officiels des facultes de Droit, Paris, Librairie du Recueil Sirey, 1932, 2a édition, volume 1;

KRETSCHMANN, Jenny Griziotti, Storia delle dottrine economiche, $2^{\mathrm{a}}$ edição, Torino, Unione Tipografico-Editrice Torinese, 1954; 
LAGO, Ivan Jacopetti do, O tratamento jurídico da venda de imóvel com divergência de área na evolução do Direito Brasileiro: venda ad corpus e ad mensuram, Tese de doutorado, Faculdade de Direito da Universidade de São Paulo, São Paulo, 2014;

LA TOUR DU PIN, François René de, Marquês de Chambly de La Charce, Vers un ordre social chrétien: jalons de route 1882-1907, 3ª edição, Paris, Nouvelle Librairie nationale, s/d;

LARANJEIRA, Raymundo, Propedêutica do Direito Agrário, $2^{\mathrm{a}}$ edição, São Paulo, LTR, 1981;

(Coordenador) Direito Agrário Brasileiro:

Em homenagem à memória de Fernando Pereira Sodero, São Paulo, LTR, 1999;

LEÃO XIII, Carta Encíclica Rerum Novarum, dada em Roma aos 15 de maio de 1891. Disponível em: https://w2.vatican.va/content/leoxiii/pt/encyclicals/documents/hf_1-xiii_enc_15051891_rerum-

novarum.html. Acesso em 10 de agosto de 2019;

, Carta Encíclica Libertas, dada em Roma aos 20 de junho de 1888. Disponível em: http://w2.vatican.va/content/leoxiii/la/encyclicals/documents/hf_1-xiii_enc_20061888_libertas.html

Acesso em 5 de agosto de 2019;

, Carta Encíclica Immortale Dei, dada em Roma a $1^{\circ}$ de novembro de 1885. Disponível em: http://www.vatican.va/content/leoxiii/pt/encyclicals/documents/hf_1-xiii_enc_01111885_immortale-

dei.html. Acesso em 10 de agosto de 2019;

, Carta Encíclica Quod apostolici muneris, dada em Roma aos 28 de dezembro de 1878 . Disponível em: http://www.vatican.va/content/leo-xiii/la/encyclicals/documents/hf_1xiii_enc_28121878_quod-apostolici-muneris.html. Acesso em 10 de agosto de 2019;

, Carta Encíclica Au milieu des sollicitudes, dada em Roma aos 16 de fevereiro de 1892. Disponível em: 
http://www.vatican.va/content/leo-xiii/fr/encyclicals/documents/hf_1-

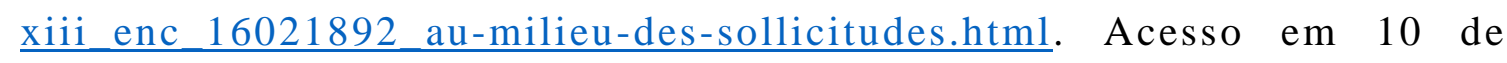
agosto de 2019;

LESSA, Luiz Carlos, Dicionário de Doutrina Social da Igreja: Doutrina Social da Igreja de A a Z, São Paulo, LTr, 2004;

LÉVY, Jean-Philippe, História da propriedade, Tradução de Fernando Trigueiro, Lisboa, Estampa, 1973;

LIMA, Alceu Amoroso (Tristão de Athayde), Introdução à Economia Moderna, $2^{a}$ edição, Rio de Janeiro, Civilização Brasileira, 1933; , Política, $1^{\mathrm{a}}$ edição, Rio de Janeiro, Livraria

Católica, 1932; , Problema da burguezia, Rio de Janeiro, Schmidt, 1932; _, Preparação à Sociologia, $3^{\mathrm{a}}$ edição, Rio de Janeiro, Editora Getulio Costa, s/d; , O existencialismo e outros mitos do nosso tempo, in Obras completas de Alceu Amoroso Lima, Tomo 18, Rio de Janeiro, Livraria AGIR Editora, 1956;

, Catholicismo burguez, in A Ordem, $\mathrm{n}^{\circ} 62$ (nova série), Rio de Janeiro, abril de 1935, pp. 257-266;

LIMA, Rafael Augusto de Mendonça, Direito Agrário, 2a edição, Rio de Janeiro, Renovar, 1997

LIMA, Ruy Cirne, Pequena história territorial do Brasil: Sesmarias e terras devolutas, $1^{\text {a }}$ edição, Porto Alegre, Sulina, 1954;

LOPES, Miguel Maria de Serpa, Curso de Direito Civil, volume VI, $2^{\mathrm{a}}$ edição, Rio de Janeiro, Livraria Freitas Bastos, 1962;

LUDWIG, Emil, Stalin, Tradução de Eduardo de Lima Castro, Rio de Janeiro, Editorial Calvino Limitada, 1943; 
MACHADO, Hermano Augusto, A função social e a tipificação no direito de propriedade, in Revereor: Estudos jurídicos em homenagem à Faculdade de Direito da Bahia, São Paulo, Saraiva, 1981, pp. 233-258;

MAIA, J. Motta, Explicação ao leitor, in Idem (Com. e anot.), Estatuto da Terra, Rio de Janeiro, A. Coelho Branco F. ${ }^{\circ}$, Editor, 1965;

MALUF, Carlos Alberto Dabus, Limitações ao direito de propriedade, $1^{\mathrm{a}}$ edição, Prefácio de Miguel Reale, São Paulo, Saraiva, 1997; , Limitações ao direito de propriedade, $3^{\mathrm{a}}$ edição revista e atualizada, Prefácio de Miguel Reale, São Paulo, Editora Revista dos Tribunais, 2011;

MANSER, OP, Gallus M., La esencia del tomismo, Tradução espanhola de Valentín García Yebra, Madrid, Instituto "Luis Vives" de Filosofía, Consejo Superior de Investigaciones Científicas, 1947;

MARITAIN, Jacques, Le Docteur Angélique, 2a edição, Paris, Desclée de Brouwer, 1930;

MAROI, Fulvio, Proprietà, in SCIALOJA, Vittorio (Dir.), Dizionario pratico del Diritto Privato, Milano, Vilardi, volume 5, pp. 693 e ss.;

MARQUES, Benedito Ferreira, Direito Agrário no Brasil, $11^{\text {a }}$ edição, revista e ampliada, São Paulo, Atlas, 2015;

MARTÍN ARTAJO, Alberto e CUERVO, Maximo, Doctrina Social Católica de León XIII y Pío XI, Barcelona, Labor, 1939;

MARTíneZ, Pedro Soares, Economia Política, $8^{\text {a }}$ edição revista, Coimbra, Livraria Almedina, 1998;

MARX, Karl e ENGELS, Friedrich, Manifesto do Partido Comunista, Tradução de Marcus Vinicius Mazzari. Disponível em: http://www.scielo.br/scielo.php?script=sci_arttext\&pid=S0103-

40141998000300002. Acesso em 15 de agosto de 2019;

MEINVIELlE, Julio, Concepción católica de la Economía, Buenos Aires, Cursos de Cultura Católica, 1936; 
MENDES, Gilmar Ferreira; COELHO, Inocêncio Mártires; BRANCO, Paulo Gustavo Gonet, Curso de Direito Constitucional, $2^{\mathrm{a}}$ edição revista e ampliada, São Paulo, Saraiva, 2008;

MESSINEO, Francesco, Manuale di Diritto Civile e Commerciale (codici e legislazione complementare), Volume II, $7^{\text {a }}$ edição, Milano, A. Giuffrè, 1947 ;

MESSNER, Johannes, Ética Social (o Direito Natural no Mundo Moderno), Tradução de Alípio Maia de Castro, São Paulo, Editora Quadrante, Editora da Universidade de São Paulo, s/d;

MICHEL, Suzanne, La notion thomiste du Bien Commun, Prefácio de Georges Renard, Paris, Librairie Philosophique J. Vrin, 1932 ;

MIRANDA, Francisco Cavalcanti Pontes de, Fontes e evolução do Direito Civil Brasileiro, $2^{\mathrm{a}}$ edição, Rio de Janeiro, Forense, 1981;

\section{Comentários}

$\grave{a}$

Constituição de 1967, com a Emenda $n^{o}$ 1, de 1969, Tomo VI, $2^{\text {a }}$ edição, revista, 2a tiragem, São Paulo, Revista dos Tribunais, 1974;

Comentários

Constituição de 1967, com a Emenda $n^{o} 1$, de 1969, Tomo V, $3^{\text {a }}$ edição, Rio de Janeiro, Forense, 1987;

Tratado de Direito Privado:

Parte especial, Tomo XI, $1^{\text {a }}$ edição, Rio de Janeiro, Editor Borsoi, 1955;

Comentários

$\grave{a}$

Constituição da República dos Estados Unidos do Brasil, Volume I, Rio de Janeiro, Editora Guanabara, 1937;

MONTEIRO, Washington de Barros e MALUF, Carlos Alberto Dabus, Curso de Direito Civil, volume 3, Direito das coisas, $43^{\text {a }}$ edição, São Paulo, Saraiva, 2013;

MORAES JÚNIOR, D. Antônio de Almeida, A Igreja e o comunismo, Petrópolis, Editora Vozes Limitada, 1962; 
MORIN, Gaston, L'euvre de Duguit et le Droit Privé, in Archives de Philosophie du Droit et de Sociologie Juridique, ns.1-2, Paris, Recueil Sirey, 1932, pp. 143-162;

La révolte $d u$ Droit contre le Code: La révision nécessaire des concepts juridiques, Paris, Librairie du Recueil Sirey, 1945; , Le sens de l'évolution contemporaine du droit de propriété, in Le droit privé français au milieu du XXe siècle: Études offertes à Georges Ripert, Tomo II, Paris, R. Pichon et R. Durand-Auzias, 1950, pp. 3-16;

MUSSOLINI, Benito, Discorso del XIII gennaio per lo Stato Corporativo, in Scritti e discorsi, Milano, Hoepli, 1935, pp. 13-22;

NERY JUNIOR, Nelson, e NERY, Rosa Maria de Andrade, Código Civil comentado, $6^{\mathrm{a}}$ edição, revista, ampliada e atualizada até 28 de março de 02008, São Paulo, Editora Revista dos Tribunais, 2008;

NOGUEIRA, José Carlos de Ataliba, O Estado é um meio e não um fim, $1^{\mathrm{a}}$ edição, São Paulo, Revista dos Tribunais, 1940;

O’BRIEN, George, An Essay on Medieval Economic Teaching, $1^{\mathrm{a}}$ edição, London, Longman Green \& Co., 1920;

OLIVEIRA, Juarez de (Organizador), Estatuto da Terra, $8^{\mathrm{a}}$ edição, atualizada, São Paulo, Saraiva, 1993;

ODDONE, SJ, Andrea, Princípios cristãos para o estudo da Sociologia, Tradução do Padre Carlos Piasentin, CPS, Prefácio de Plínio Salgado, São Paulo, Gráfica Tibiriçá, 1952;

OLIVEIRA, Gilberto Callado de, Filosofia da política jurídica, $2^{\mathrm{a}}$ edição, Florianópolis, Conceito Editorial, 2008;

OLIVEIRA, Moacyr Velloso Cardoso de OLIVEIRA, A Doutrina Social ao alcance de todos, São Paulo, LTr, 1991;

OLIVIER-MARTIN, François, L'organisation corporative de la France d'Ancien Régime, Paris, Sirey, 1938; 
OZANAM, Antoine Frédéric, Droit public - Des biens de l'Église, in Mélanges: Religion, Philosophie, Politique, Jurisprudence, Biographies, Discours, Voyages, Paris, Librairie Jacques Lecoffre, 1872 ; Réflexions sur la doctrine de Saint-Simon,

Lyon, Perisse frères, 1831 ;

PASCOAES, Teixeira de (pseudônimo de Joaquim Pereira Teixeira de Vasconcelos), Arte de ser português, $2^{\text {a }}$ edição, Porto, Renascença Portuguesa, 1920;

PAUlO VI, São, Carta Encíclica Populorum Progressio, dada em Roma aos 26 de março de 1967. Disponível em: http://www.vatican.va/content/paul-vi/pt/encyclicals/documents/hf_pvi_enc_26031967_populorum.html. Acesso em 10 de agosto de 2019; , Constituição Pastoral Gaudium et Spes, dada em Roma aos 7 de dezembro de 1965. Disponível em: http://www.vatican.va/archive/hist_councils/ii_vatican_council/document s/vat-ii_const_19651207_gaudium-et-spes_po.html. Acesso em 10 de agosto de 2019;

- Discurso del Papa Pablo VI a una peregrinación eslovaca, de 14 de setembro de 1963. Disponível em: http://www.vatican.va/content/paul-vi/es/speeches/1963/documents/hf_pvi_spe_19630914_slovak-pilgrims.html. Acesso em 10 de agosto de 2019; PAUPÉRIO, Arthur Machado, Introdução ao Estudo do Direito, $3^{\mathrm{a}}$ edição, Rio de Janeiro, Forense, 1993; A concepção cristã da propriedade e sua função social, in Revista de Informação Legislativa, Brasília, ano 24, número 93, jan./mar. de 1987, p. 213-228; , Teoria Geral do Estado, $7^{\mathrm{a}}$ edição, Rio de Janeiro, Forense, 1979; O Estado e a realidade nacional, Rio de Janeiro, Academia Brasileira de Ciências Morais e Políticas, 1991; 
Introdução à Ciência do Direito, $3^{\mathrm{a}}$

edição, $5^{\text {a }}$ tiragem, Rio de Janeiro, Forense, 2001;

PENTEADO, Luciano de Camargo, Direito das coisas, $2^{\mathrm{a}}$ edição revista, atualizada e ampliada, São Paulo, Editora Revista dos Tribunais, 2012;

PEREIRA, Lafayette Rodrigues, Direito das coisas, Adaptação ao Código Civil por José Bonifácio de Andrada e Silva, 5a edição, volume I, Rio de Janeiro, Livraria Editora Freitas Bastos, 1943;

PEREIRA, Caio Mário da Silva, Instituições de Direito Civil, volume IV, $13^{a}$ edição, Rio de Janeiro, Editora Forense, 1999;

PEREIRA, Virgílio de Sá, Direito das coisas: Da propriedade, $2^{\text {a }}$ edição histórica atualizada legislativamente, Rio de Janeiro, Forense, 2007, in LACERDA, Paulo, Manual do Código Civil Brasileiro, $2^{\mathrm{a}}$ edição, Volume VIII;

PERNOUD, Régine, Luz sobre a Idade Média, Tradução de António Manuel de Almeida Gonçalves, Lisboa, Publicações Europa-América, 1997;

PESCH, Heinrich, Lehrbuch der Nationalökonomie/Teaching Guide to Economics: Economic Systems and the Nature and Dispositional Causes of the Wealth of a Nation, Volume IV, Livro II, Tradução inglesa de Rupert J. Ederer, Lewiston, NY, Edwin Mellen Press, 2002;

, Ethics and the national economy, Tradução de Rupert

J. Ederer, Norfolk, Virginia, IHS Press, 2004;

PIEPER, Josef, Virtudes fundamentais, Tradução de Narino e Silva e Beckert da Assumpção, Lisboa, Editorial Aster, 1960;

PIO X, São, Carta Encíclica Iucunda Sane, dada em Roma aos 12 de março de 1904. Disponível em: http://www.vatican.va/content/piusx/la/encyclicals/documents/hf_p-x_enc_12031904_iucunda-sane.html. Acesso em 10 de agosto de 2019;

PIO XI, Carta Encíclica Quadragesimo Anno. Disponível em: https://w2.vatican.va/content/pius-xi/pt/encyclicals/documents/hf_pxi_enc_19310515_quadragesimo-anno.html. Acesso em 10 de agosto de 2019; 
, Carta Encíclica Mit Brennender Sorge, dada no Vaticano aos 14 de março de 1937. Disponível em: http://w2.vatican.va/content/piusxi/de/encyclicals/documents/hf_p-xi_enc_14031937_mit-brennendersorge.html. Acesso em 5 de agosto de 2019;

, Carta Encíclica Caritate Christi Compulsi, dada em Roma aos 3 de maio de 1932. Disponível em: http://www.vatican.va/content/piusxi/la/encyclicals/documents/hf_p-xi_enc_19320503_caritate-christicompulsi.html. Acesso em 10 de agosto de 2019;

, Carta Encíclica Divini Redemptoris, dada em Roma aos 19 de março de 1937. Disponível em: http://www.vatican.va/content/piusxi/pt/encyclicals/documents/hf_p-xi_enc_19370319_divini-

redemptoris.html. Acesso em 10 de agosto de 2019;

, Carta Encíclica Casti Connubii, dada em Roma aos 31 de dezembro de 1930. Disponível em: http://www.vatican.va/content/piusxi/la/encyclicals/documents/hf_p-xi_enc_19301231_casti-connubii.html.

Acesso em 10 de agosto de 2019;

PIO XII, Discorsi e Radiomessaggi di Sua Santità Pio XII, Città del Vaticano, Tipografia Poliglotta Vaticana, 1939-1958 (20 volumes);

, Radiomensagem na solenidade de Pentecostes, de $1^{\circ}$ de junho de 1941. Disponível em: https://w2.vatican.va/content/pius $\mathrm{xii} / \mathrm{pt} / \mathrm{speeches} / 1941 /$ documents/hf_p-xii_spe_19410601_radiomessagepentecost.html. Acesso em 10 de agosto de 2019;

Discorso di Sua Santità Pio XII ai filosofi umanisti convenuti a Roma per il loro congresso Internazionale, de 25 de setembro de 1949. Disponível em: https://w2.vatican.va/content/piusxii/it/speeches/1949/documents/hf_p-xii_spe_19490925_grandcoeur.html. Acesso em 5 de agosto de 2019;

Radiobotschaft von Papst Pius XII. Zum 77, Katholikentag, de 2 de setembro de 1956. Disponível em: https://w2.vatican.va/content/piusxii/de/speeches/1956/documents/hf_p-

xii_spe_19560902_katholikentag.html. Acesso em 5 de agosto de 2019; 
, Carta Encíclica Summi Pontificatus, dada em Castelgandolfo aos 20 de outubro de 1939. Disponível em: https://w2.vatican.va/content/piusxii/pt/encyclicals/documents/hf_p-xii_enc_20101939_summipontificatus.html. Acesso em 5 de agosto de 2019;

Discorso di Sua Santità Pio XII ai lavoratori dele A.C.L.I. (Associazioni Cristiane dei Lavoratori Italiani), de 14 de maio de 1953. Disponível em: https://w2.vatican.va/content/piusxii/it/speeches/1953/documents/hf_p-xii_spe_19530514_lavoratoriacli.html. Acesso em 5 de agosto de 2019;

, Carta Encíclica Humani Generis, dada em Roma aos 12 de agosto de 1950. Disponível em: http://w2.vatican.va/content/piusxii/pt/encyclicals/documents/hf_p-xii_enc_12081950_humanigeneris.html. Acesso em 5 de agosto de 2019;

, Alocução no IV Centenário da Pontifícia Universidade Gregoriana, de 17 de outubro de 1953. Disponível em: https://w2.vatican.va/content/pius-xii/la/speeches/1953/documents/hf_pxii_spe 19531017_universita-gregoriana.html. Acesso em 6 de agosto de 2019.

, Discorso du Sua Santità Pio XII al Sacro Collegio dei Cardinali e alla Prelatura Romana, de 24 de dezembro de 1940, Disponível em: https://w2.vatican.va/content/pius-xii/it/speeches/1940/documents/hf_pxii_spe_19401224_venerabili-fratelli.html. Acesso em 6 de agosto de 2019 ;

Radiomensagem do Santo Padre Pio XII: Con sempre nuova freschezza. Disponível em: https://w2.vatican.va/content/pius$\underline{\mathrm{xii} / \mathrm{pt} / \mathrm{speeches} / 1942 / \text { documents/hf_p-xii_spe_19421224_radiomessage- }}$ christmas.html. Acesso em 10 de agosto de 2019;

, Radiomessaggio di Sua Santità Pio XII nel V anniversario dall'inizio della Guerra Mondiale, de $1^{\circ}$ de setembro de 1944. Disponível em:

https://w2.vatican.va/content/pius-

xii/it/speeches/1944/documents/hf_p-xii_spe_19440901_al-

compiersi.html. Acesso em 10 de agosto de 2019; 
, Discorso di Sua Santità Pio XII al Sacro Collegio nella festività di Sant'Eugenio, de 2 de junho de 1948. Disponível em: https://w2.vatican.va/content/pius-xii/it/speeches/1948/documents/hf_pxii_spe_19480602_sacro-collegio.html. Acesso em 10 de agosto de 2019; , Discours du Pape Pie XII, aux participants à la conférence internationale sur les relations humaines dans l'industrie, de $4 \mathrm{de}$ fevereiro de 1956. Disponível em : https://w2.vatican.va/content/pius$\underline{\text { xii/fr/speeches/1956/documents/hf_p-xii_spe_19560204_conferenza- }}$ industria.html. Acesso em 10 de agosto de 2019;

, Discorso di sua santità Pio XII ai lavoratori degli stabilimenti FIAT di Torino, de 31 de outubro de 1948. Disponível em: https://w2.vatican.va/content/pius-xii/it/speeches/1948/documents/hf_pxii_spe_19481031_lavoratori-fiat.html. Acesso em 10 de agosto de 2019; , Discorso di sua santità Pio PP. XII ai professori e agli alunni del Liceo-Ginnasio “Ennio Quirino Visconti”, de 28 de fevereiro de 1957. Disponível em: https://w2.vatican.va/content/pius$\underline{\text { xii/it/speeches/1957/documents/hf_p-xii_spe_19570228_liceo- }}$

visconti.html. Acesso em 10 de agosto de 2019;

, Radiomessaggio di Sua Santità Pio XII in occasione del Santo Natale, de 23 de dezembro de 1949. Disponível em: http://www.vatican.va/content/pius-xii/it/speeches/1949/documents/hf_pxii_spe_19491224_radiomessage-holy-year.html. Acesso em 10 de agosto de 2019;

, Discorso di Sua Santità Pio XII agli uomini di Azione Cattolica, de 7 de setembro de 1947. Disponível em: http://www.vatican.va/content/pius-xii/it/speeches/1947/documents/hf_pxii_spe_19470907_uomini-azione-cattolica.html. Acesso em 10 de agosto de 2019;

, Radiomessaggio di Sua Santità Pio XII per celebrare il Natale dell'Anno Santo, de 23 de dezembro de 1950. Disponível em: https://w2.vatican.va/content/pius-xii/it/speeches/1950/documents/hf_pxii_spe_19501223_un-anno.html. Acesso em 10 de agosto de 2019; 
, Radiomessaggio di Sua Santità Pio XII ai popoli del mondo intero, de 24 de dezembro de 1944. Disponível em: https://w2.vatican.va/content/pius-xii/it/speeches/1944/documents/hf_pxii_spe_19441224_natale.html. Acesso em 10 de agosto de 2019; , Message-Radio du Pape Pie XII aux participants au VII Congrès International des Médecins Catholiques, de 11 de setembro de 1956. Disponível em : $\quad$ https://w2.vatican.va/content/piusxii/fr/speeches/1956/documents/hf_p-xii_spe_19560911_medicicattolici.html. Acesso em 10 de agosto de 2019;

, Discorso di Sua Santità Pio XII ad um grupo di alti funzionari degli Stati Uniti. Disponível em: http://www.vatican.va/content/piusxii/en/speeches/1947/documents/hf_p-xii_spe_19470716_funzionari-statiuniti.html. Acesso em 10 de agosto de 2019;

, Il nostro predecessore, in Federico RODRÍGUEZ (Organizador), Doctrina pontificia, III: Documentos sociales, $2^{\mathrm{a}}$ edição, Madrid, Biblioteca de Autores Cristianos (BAC), 1964, pp. 905-911;

, Discours du Pape Pie XII aux participants au VIII Congrès International des Sciences Administratives, de 5 de agosto de 1950. Disponível em : http://www.vatican.va/content/piusxii/fr/speeches/1950/documents/hf_p-xii_spe_19500805_scienzeamministrative.html. Acesso em 10 de agosto de 2019; , Discours du Pape Pie XII aux participants au Congrès International d'Études Sociales. Disponível em: http://www.vatican.va/content/pius-xii/fr/speeches/1950/documents/hf_pxii_spe_19500603_studi-sociali.html. Acesso em 10 de agosto de 2019; , Discours du Pape Pie XII aux congressistes de l'Union Internationale des Associations Patronales Catholiques. Disponível em: http://www.vatican.va/content/pius-xii/fr/speeches/1949/documents/hf_pxii_spe_19490507_associations-patronales.html. Acesso em 10 de agosto de 2019;

La verdadera noción del Estado (discurso aos participantes do VIII Congresso Internacional das Ciências Administrativas, de 5 de agosto 
de 1950), in José Luis GUTIÉRREZ GARCÍA (Organizador), Doctrina Pontificia II: Documentos Políticos, Madrid, Biblioteca de Autores Cristianos (BAC), 1958, pp. 976-979;

PINTO, O fundamento do imposto, Tese de concurso para Lente Catedrático de Ciência das Finanças da Faculdade de Direito do Paraná, Curitiba, Papelaria Irmãos Guimarães, 1936;

PINTO JUNIOR, Joaquim Modesto e FARIAS, Valdez, Coletânea de Legislação e Jurisprudência Agrária e Correlata, Volume III, $1^{\text {a }}$ edição, Brasília, Ministério do Desenvolvimento Agrário, 2007;

PIRENNE, Henri, História econômica e social da Idade Média, $1^{\text {a }}$ edição, Tradução de Lycurgo Gomes da Motta, São Paulo, Mestre Jou, 1963;

PLATÃO, Timeu, in Diálogos $V$, Tradução de Edson Bini, $1^{\text {a }}$ edição, Bauru, SP, EDIPRO, 2010 ;

, A República, Tradução de Anna Lia Amaral de Almeida Prado, $1^{\text {a }}$ edição, $2^{\text {a }}$ tiragem, São Paulo, Martins Fontes, 2009;

, Górgias, 483-484, in Diálogos I, Tradução de Edson Bini, $1^{\text {a }}$ edição, Bauru, SP, EDIPRO, 2007;

, Protágoras, in Diálogos I, Tradução de Edson Bini, $1^{\text {a }}$ edição, Bauru, SP, EDIPRO, 2007;

POLETTI, Ronaldo, Constituição anotada, Rio de Janeiro, Forense, 2009; 1934 (Coleção Constituições Brasileiras, Volume 3),

$3^{a}$ edição, Brasília, Senado Federal, Subsecretaria de Edições Técnicas, 2012);

PONTIFÍCIO CONSELHO “JUSTIÇA E PAZ”, Compêndio da Doutrina Social da Igreja, Tradução da Conferência Nacional dos Bispos do Brasil (CNBB), $7^{\text {a }}$ edição, São Paulo, Paulinas, 2011;

PORTO, José Antônio da Costa, Estudo sobre o sistema sesmarial, Recife, Imprensa Universitária, 1965;

PORTO, Walter Costa, 1937 (Coleção Constituições Brasileiras, Volume 4), $3^{a}$ edição, Brasília, Senado Federal, Subsecretaria de Edições Técnicas, 2012); 
POVEDA VELASCO, Ignacio Maria, Ordenações do Reino de Portugal, in Revista da Faculdade de Direito da USP, volume 89, São Paulo, 1994, pp. 11-67;

PRADERA, Víctor, O Novo Estado, Tradução portuguesa, Lisboa, Edições Gama, 1947;

PROUDHON, Pierre-Joseph, Qu'est-ce que la propriété? ou Recherche sur le principe $d u$ Droit et $d u$ Gouvernement, $1^{\mathrm{a}}$ edição, Paris, Librairie de Prevot, 1841;

, Théorie de la propriété, Paris, A. Lacroix,

Verboeckhover et Cie, 1866;

, Manifeste $d u$ Peuple. Disponível em:

https://comptoir.org/2016/01/18/manifeste-du-peuple-de-proudhon/.

Acesso em 10 de agosto de 2019. Texto originalmente publicado no jornal Le peuple, de Paris, aos 2 de setembro de 1848;

, Les Confessions d'um révolutionnaire, pour servir à l'histoire de la révolution de Février, $3^{\mathrm{a}}$ edição, revista, corrigida e aumentada pelo autor, Paris, Garnier frères, 1851;

QUEIROZ, Paulo Edmur de Souza, Sociologia política de Oliveira Vianna. São Paulo, Editora Convívio, 1975;

RAMALHETE, Carlos, Doutrina Social da Igreja: uma introdução, São Paulo, Quadrante, 2017;

RAU, Virgínia, Sesmarias medievais portuguesas, Lisboa. Editorial Presença, 1982;

REALE, Giovanni, e ANTISERI, Dario História da Filosofia, Volume 2 (Patrística e Escolástica), Tradução de Ivo Storniolo, São Paulo, Paulus, 2005;

REALE, Miguel, Visão geral sobre o novo Código Civil. Disponível em: http://www.miguelreale.com.br/artigos/vgpcc.htm. Acesso em 11 de janeiro de 2020 ;

O Projeto do novo Código Civil, São Paulo, Saraiva, 1999; 
, O capitalismo internacional, $2^{\text {a }}$ edição, in Obras políticas ( $1^{a}$ fase - 1931/1937), Tomo 2, Brasília, Editora Universidade de Brasília, 1983;

, Filosofia do Direito, $19^{\mathrm{a}}$ edição, São Paulo, Editora

Saraiva, 1999;

, Súmula do Integralismo (1935), in Perspectivas Integralistas (1935), $3^{\text {a }}$ edição, in Obras políticas (1931/1937), Volume 3, Brasília, Editora Universidade de Brasília, 1983, pp. 15-35;

O Projeto de Código Civil: Situação atual e seus problemas fundamentais, São Paulo, Saraiva, 1986;

Atualidades de um Mundo Antigo, $2^{\mathrm{a}}$ edição, in Obras políticas ( $1^{\text {a }}$ fase-1931-1937), tomo I, Brasília, Editora Universidade de Brasília, 1983;

, Teixeira de Freitas e o sentido social do Direito, in

Figuras da inteligência brasileira, 2a edição, São Paulo, Siciliano, 1994, pp. 35-44;

RENARD, Raymond-Georges, L'Église et la Question Sociale, Paris, Éditions du Cerf, 1937;

RIPERT, Georges, Le déclin du Droit, Paris, Librairie Générale de Droit et de Jurisprudence, 1949;

ROCHA, Olavo Acyr de Lima, As Ordenações Filipinas e o Direito Agrário, in Revista da Faculdade de Direito da Universidade de São Paulo, v. 95, São Paulo, jan./dez. 2000;

RODRIGUES, Antônio Coelho, Projecto do Codigo Civil Brazileiro: Precedido de um projecto de lei preliminar, Rio de Janeiro, Imprensa Nacional, 1893;

RODRIGUES, Félix Contreiras, Conceitos de valor e preço (Fundamentos para uma Ordem Nova Corporativa), Rio de Janeiro, Gráfica Olímpica Editora, 1951; 
A propriedade e o ensinamento integralista,

in Enciclopédia do Integralismo, volume III, Rio de Janeiro, Edições GRD, Livraria Clássica Brasileira, 1958, pp. 137-142;

RODRIGUES, Sílvio, Direito Civil, volume 5: Direito das Coisas, $28^{\mathrm{a}}$ edição rev. e atual. de acordo com o novo Código Civil, São Paulo, Saraiva, 2003;

RODRIGUES JUNIOR, Otavio Luiz, Propriedade e função social: exame crítico de um caso de "constitucionalização" do Direito Civil, in SOUSA, Marcelo Rebelo de; QUADROS, Fausto de; PINTO, Eduardo Vera-Cruz (Coordenadores), Estudos em homenagem ao Professor Doutor Jorge Miranda, Coimbra, Coimbra Editora, pp. 61-89;

RODRÍGUEZ, Federico (Organizador), Doctrina pontificia, III: Documentos sociales, $2^{\mathrm{a}}$ edição, Madrid, Biblioteca de Autores Cristianos (B AC), 1964;

ROGEIRO, Nuno, A Lei Fundamental da República Federal da Alemanha, Coimbra, Coimbra Editora, 1996;

ROMMEN, Heinrich, O Estado no pensamento católico: Tratado de filosofia política, Tradução das monjas beneditinas da Abadia de Santa Maria, em São Paulo, São Paulo, Edições Paulinas, 1967;

ROTHE, Tancrède, De l'existence de la propriété: Idées personnelles, opinions diverses, Paris, Librairie du Recueil Sirey, 1930;

ROUSSEAU, Jean-Jacques, O Contrato Social (princípios de Direito Político), Tradução de Antonio de Pádua Danesi, $3^{a}$ edição, $3^{a}$ tiragem, São Paulo, Martins Fontes, 1999;

RUTTEN, G. C., OP, A Doutrina Social da Igreja, segundo as encíclicas "Rerum Novarum" e "Quadragesimo Anno, Rio de Janeiro, Livraria AGIR Editora, 1946;

SACHERI, Carlos Alberto, A Ordem Natural: Um compêndio sobre a Doutrina Social da Igreja, Tradução de Roberto Romano, Belo Horizonte, Edições Cristo Rei, 2014; 
SAlGADO, Plínio, Direitos e deveres do Homem, $4^{\text {a }}$ edição, in Obras completas, $2^{a}$ edição, volume 5, São Paulo, Editora das Américas, 1957; , Discursos parlamentares (Volume 18 - Plínio Salgado), Seleção e introdução de Gumercindo Rocha Dorea, Brasília, Câmara dos Deputados, 1982 , O ritmo da História, $3^{\mathrm{a}}$ edição (em verdade $4^{\mathrm{a}}$ ), São Paulo, Voz do Oeste; Brasília, INL (Instituto Nacional do Livro), 1978; - Atualidades brasileiras, $2^{\mathrm{a}}$ edição, in Obras completas, $2^{a}$ edição, volume 16, São Paulo, Editora das Américas, 1959; - Carta de Princípios do Partido de Representação Popular, Edição do Comitê de Propaganda pró Candidatura de Plínio Salgado, 1955; , Como nasceram as cidades do Brasil, $5^{\mathrm{a}}$ edição, Prefácio de Euro Brandão, São Paulo/Brasília, Voz do Oeste/Instituto Nacional do Livro, 1978;

, Espírito da burguesia, $1^{\text {a }}$ edição, Rio de Janeiro, Livraria Clássica Brasileira, 1951;

Estado Totalitário e Estado Integral, in Madrugada do Espírito, $4^{\text {a }}$ edição, in Obras Completas. $2^{a}$ edição, volume 7, São Paulo, Editora das Américas, 1957, pp. 443-449 (artigo publicado originalmente no jornal A Offensiva, do Rio de Janeiro, em $1^{\circ}$ de novembro de 1936);

SALlERON, Louis, Diffuser la Proprieté, Paris, Nouvelles Éditions Latines, 1964;

, Liberalismo e socialismo, Tradução de João Benedicto Martins Ramos, São Paulo, Mundo Cultural, 1979;

SALVADOR, Frei Vicente do, Historia do Brazil, in Annaes da Biblioteca Nacional, Volume XIII, Rio de Janeiro, Typographia Leuzinger \& Filhos, 1889; 
SANTOS, Arlindo Veiga dos, Filosofia política de Santo Tomás de Aquino, $3^{a}$ edição, melhorada, Prefácio do Prof. Dr. L. Van Acker, São Paulo, José Bushatsky, Editor, 1956;

, Sob o signo da fidelidade: considerações históricas, São Paulo, Pátria-Nova, s/d;

, Ideias que marcham no silêncio, São

Paulo, Pátria-Nova, 1962;

, Para a Ordem Nova, São Paulo, Pátria-

Nova, 1933;

SANTOS, Eduardo Sens dos, A função social do contrato, Florianópolis, $\mathrm{OAB} / \mathrm{SC}$ Editora, 2004;

SANTOS, Joaquim Felício dos, Projecto do Codigo Civil Brazileiro e Commentario, Volume 2, Rio de Janeiro, H. Laemmert., 1885;

SARDINHA, António, Da hera nas colunas: novos estudos, Coimbra, “Atlântida” Livraria Editora, 1928;

Ao princípio era o Verbo, $2^{\mathrm{a}}$ edição, Lisboa,

Editorial Restauração, 1959;

SCAFF, Fernando Campos, Direito Agrário: Origens, evolução $e$ biotecnologia, São Paulo, Atlas, 2012;

SCHELER, Max, Vom Umsturz der Werte, Bern, Francke, 1955;

SCHREYVOGL, Friedrich, Ausgewaehlte Schriften zur Staats - und Wirtschaftslehre des Thomas von Aquino, Jena, G. Fischer, 1923;

SCIACCA, Michele Federico, A hora de Cristo, Tradução e prólogo de Carlos Eduardo de Soveral, Lisboa, Editorial Aster, 1959;

, Revolución, Conservadurismo, Tradición, in Verbo, série XIII, número 123, Madrid, Mar. de 1974, pp. 283-296;

SIERRA BRAVO, Restituto, La persona humana en el magisterio social de Pio XII, Madrid, Editorial Aguilar, 1960;

SILVA, José Bonifácio de Andrada e. Lembranças e apontamentos do governo provisório da Província de São Paulo para os seus deputados. 
Negócios do Reino do Brasil, in CALDEIRA, Jorge (Org. e intr.), José Bonifácio de Andrada e Silva, São Paulo, Editora 34, 2002, pp. 124-133;

SILVA, Lúcio Craveiro da, A idade do social: Ensaio sobre a evolução da sociedade contemporânea, $2^{\mathrm{a}}$ edição, aumentada, Braga, Livraria Cruz, 1959 ;

SILVA, Virgílio Afonso da, $O$ conteúdo essencial dos direitos fundamentais e a eficácia das normas constitucionais, in Revista de Direito do Estado, Volume 4, Rio de Janeiro, 2006, pp. 23-51;

SILVEIRA, Tasso da, Estado Corporativo, Rio de Janeiro, Livraria José Olympio Editora, 1937;

SODERO, Fernando Pereira, Direito agrário e reforma agrária, São Paulo, Livraria Legislação Brasileira, 1968;

O Estatuto da Terra, Brasília, Fundação

Petrônio Portella, 1982;

O módulo rural e suas implicações jurídicas,

São Paulo, LTR, 1975;

Direito agrário - I, in FRANÇA, Rubens

Limongi (coord.), Enciclopédia Saraiva de Direito, vol. 25. São Paulo:

Saraiva, s/d, pp. 170-197;

SODRÉ, Ruy de Azevedo, Função social da propriedade privada, Tese de Doutorado em Filosofia do Direito, Faculdade de Direito da Universidade de São Paulo, São Paulo, Empresa Gráfica da Revista dos Tribunais, s/d.

SÓFOCLES, A trilogia tebana, Tradução do grego, introdução e notas de Mário da Gama Kury, Rio de Janeiro, Zahar, 1990;

SOMBART, Werner, Der Moderne Kapitalismus, volume I, München/Leipzig, Duncker und Humblot, 1924;

Le bourgeois, Tradução francesa de Samuel Jankélévitch, Paris, Payot, 1926;

SOUSA, José Pedro Galvão de, Iniciação à Teoria do Estado, São Paulo, Editora Revista dos Tribunais, 1976; 
Introdução à História do Direito Político

Brasileiro, $2^{a}$ edição, São Paulo, Edição Saraiva, 1962;

Política e Teoria do Estado, São Paulo, Edição

Saraiva, 1957;

SOUSA, José Pedro Galvão de; GARCIA, Clovis Lema; CARVALHO, José Fraga Teixeira de, Dicionário de Política, São Paulo, T.A. Queiroz, 1998; SOUZA, José Cavalcante de (Organizador), Os pré-socráticos (Coleção Os pensadores, volume I), $1^{\text {a }}$ edição, São Paulo, 1973;

SOUZA, José Soriano de, Princípios Gerais de Direito Público $e$ Constitucional, Recife, Casa Editora Empresa d'A Província, 1893;

SPANN, Othmar, Breve storia delle teorie economiche, Tradução italiana de O. Degregorio, Firenze, G. C. Sansoni-Editore, 1936;

SPIRITO, Ugo, Individuo e Stato nell'economia corporativa, in Idem, Il corporativismo: Dall'economia liberale al corporativismo; I fondamenti dell'economia corporativa; Capitalismo e corporativismo, Soveria Mannelli, Rubbettino, 2009, pp. 519-532;

SQUITTI, Baldassarre, Proprietà (Diritto Romano), in Enciclopedia giuridica italiana, Milano, Società Editrice, 1901, volume, parte 4, pp. 143 e ss.;

STICCO, Maria, Il pensiero sociale di San Bernardino da Siena, Milano, Società Editrice "Vita e Pensiero", 1925;

STORCH, Thomas, Pesch and the Chesterbelloc. Disponível em: https://distributistreview.com/pesch-and-the-chesterbelloc/. Acesso em 10 de agosto de 2019;

SUÁREZ, Francisco, De Legibus ac Deo Legislatore, Pars prima, Neapoli (Nápoles), Ex Typis Fibrenianis, 1872;

SUEYOSHI, Tabir Dal Poggetto Oliveira, As sesmarias nas Ordenações do Reino, in Revista da Faculdade de Direito da Universidade de São Paulo, volume 102, jan./dez. de 2007, pp. 695-711; 
TELlES JUNIOR, Goffredo, Justiça e Júri no Estado Moderno, São Paulo, Empresa Gráfica da Revista dos Tribunais, 1938;

Iniciação na Ciência do Direito, $4^{\mathrm{a}}$ edição revista e atualizada, São Paulo, Editora Saraiva, 2008; , Carta aos Brasileiros, 1977, $1^{\text {a }}$ edição, São

Paulo, Editora Juarez de Oliveira Ltda., 2007;

THEODORO JÚNIOR, Humberto, $O$ contrato e sua função social, $2^{\circ}$ edição, Rio de Janeiro, Forense, 2004;

THOMPSON, James Westfall, An Economic and Social History of the Middle Ages (300-1300), New York/London, Century Company, 1928;

TOMASEVICIUS FILHO, Eduardo, A função social do contrato: Conceito e critérios de aplicação, in Revista de Informação Legislativa, volume 42, $\mathrm{n}^{\circ}$ 168, Brasília, Senado Federal, Subsecretaria de Edições Técnicas, out./dez de 2005, pp. 197-213;

TONIOLO, Giuseppe, Trattato di Economia Sociale e scritti economici, in Opera Omnia di Giuseppe Toniolo, Volume I, Prefácio de Francesco Vito, Città del Vaticano, Edizione del Comitato Opera Omnia di G. Toniolo, 1949;

UNIÃO INTERNACIONAL DE ESTUDOS SOCIAIS, Código Social: esboço de uma síntese social católica, São Paulo, Centro D. Vital, 1932;

UNION INTERNATIONALE D'ÉTUDES SOCIALES, Code social: esquisse d'une synthèse sociale catholique, Paris, Editions Spes, 1930;

VV.AA., A encíclica Mater et Magistra e a hodierna questão social, Tradução de Carlos Ferrario, São Paulo, Edições Paulinas, 1962;

VV.AA., Le but du Droit: bien commun, justice, sécurité, Paris, Recueil Sirey, 1938.

VV.AA., Propriétés et communautés, $2^{\mathrm{a}}$ edição, Paris, L'Arbresle, 1947;

VAllet DE GOYTISOlO, Juan, Metodología de las Leyes, Madrid, Editorial Revista de Derecho Privado/Editoriales de Derecho Reunidas, S.A., 1991; 
VÁZQUEZ DE MELlA, Juan, El concepto dinámico de la tradición (Discurso del Parque de la Salud de Barcelona, de 17 de maio de 1903). Disponível em: http://hispanismo.org/politica-y-sociedad/976-discursosde-vazquez-de-mella.html. Acesso em 10 de agosto de 2019;

VENEZIANI, Marcello, De pai para filho: elogio da Tradição, Tradução de Orlando Soares Moreira, São Paulo, Edições Loyola, 2005;

VIANA, Rui Geraldo Camargo, O parcelamento do solo urbano, Rio de Janeiro, Forense, 1985;

VIANNA, Francisco José de Oliveira, Introdução à História Social da Economia pré-capitalista no Brasil, Rio de Janeiro, Livraria José Olympio Editora, 1958;

, O problema social e a pequena propriedade, in Problemas de organização e problemas de direção, $2^{\mathrm{a}}$ edição, Prefácio de Hermes Lima, Rio de Janeiro, Record, 1974, pp. 9095 ;

, Direito do Trabalho e Democracia Social (o problema da incorporação do trabalhador no Estado), Rio de Janeiro, Livraria José Olympio Editora, 1951

VIANNA, Hélio, As sesmarias no Brasil, in VV.AA., Anais do II Simpósio dos Professores de História do Ensino Superior, Curitiba, ANPUH, 1962, pp. 247-266;

VICO, Giambattista, Autobiografia, Poesie, Scienza Nuova, $3^{\mathrm{a}}$ edição, Milano, Garzanti, 2006;

VIGNES, Bernard-Joseph-Maurice, Les doctrines économiques et morales de Saint Bernard sur la richesse et le travail, in Revue d'histoire économique et sociale, Volume 16, No. 3, Paris, 1928, pp. 547-585.

VITO, Francesco, Transformações econômicas e doutrina social católica, in VV.AA., A encíclica Mater et Magistra e a hodierna questão social, Tradução de Carlos Ferrario, São Paulo, Edições Paulinas, 1962, pp. 11 35 ; 
La riforma sociale secondo la Dottrina Cattolica, $2^{\mathrm{a}}$ edição revista, Milano, Società Editrice Vita e Pensiero, 1945;

VOEGELIN, Eric, As religiões políticas, Tradução de Teresa Marques da Silva, Lisboa, Vega Limitada, 2002.

WARD, Rufus, A Treatise on Homestead and Exemption, Chicago, T. H. Flood, 1893;

WIEACKER, Franz, História do Direito Privado Moderno, Tradução de António Manuel Botelho Hespanha, $5^{\text {a }}$ edição, Lisboa, Fundação Calouste Gulbenkian, 2015;

XENOFOnTE, Ditos e feitos memoráveis de Sócrates, Tradução de Edson Bini, $1^{\text {a }}$ edição, Bauru, SP, EDIPRO, 2006;

ZENHA, Edmundo, O Município no Brasil: 1532-1700, São Paulo, Instituto Progresso Editorial, 1948.

\section{Legislação consultada}

Código Civil de 1916;

Código Civil de 2002;

Estatuto da Terra;

Constituição Federal de 1988;

Constituição Mexicana de 1917;

Constituição Alemã de 1919;

Constituição Portuguesa de 1933;

Constituição Italiana de 1947;

Lei Federal de Bonn, de 1949;

Carta de Carnaro, de 1920:

Constituição Soviética de 1936;

Código Civil Francês de 1804;

Código Civil Italiano de 1865; 
Código Civil Italiano de 1942;

Carta do Trabalho (Carta del Lavoro), de 1927;

Constituições do Brasil, Compilação e atual. dos textos, notas, rev. e índices por Adriano Campanhole e Hilton Lobo Campanhole, 9a edição, São Paulo, Editora Atlas, 1987;

ORDENAÇÕES Afonsinas, in Collecção da Legislação Antiga e Moderna do Reino de Portugal, Parte I (Da Legislação Antiga - por resolução de S. Magestade de 02 de Setembro de 1786), Coimbra: Real Imprensa da Universidade de Coimbra, 1797;

ORDENAÇÕES Filipinas (Codigo Philippino ou Ordenações e Leis do Reino de Portugal recopiladas por mandado d'El-Rey D. Philippe I), $14^{\mathrm{a}}$ edição, Introdução e notas de Cândido Mendes de Almeida, volume IV, Rio de Janeiro, Typographia do Instituto Philomathico, 1870;

, Lisboa, Fundação Calouste Gulbenkian, 1985; reprodução fac-símile da edição brasileira de Cândido Mendes de Almeida; ORDENAÇÕES Manuelinas, in Collecção da Legislação Antiga e Moderna do Reino de Portugal - Parte I - Da Legislação Antiga - por resolução de S. Magestade de 02 de Setembro de 1786, Coimbra, Real Imprensa da Universidade de Coimbra, 1797; reprodução "fac-simile", Lisboa, Fundação Calouste Gulbenkian, 1984. 